\title{
A FINANCIAL ECONOMIC THEORY OF PUNITIVE DAMAGES
}

\begin{abstract}
Robert J. Rhee*
This Article provides a financial economic theory of punitive damages. The core problem, as the Supreme Court acknowledged in Exxon Shipping Co. $\mathrm{v}$. Baker, is not the systemic amount of punitive damages in the tort system; rather, it is the risk of outlier outcomes. Low frequency, high severity awards are unpredictable, cause financial distress, and beget social cost. By focusing only on offsetting escaped liability, the standard law and economics theory fails to account for the core problem of variance. This Article provides a risk arbitrage analysis of the relationship between variance, litigation valuation, and optimal deterrence. Starting with settlement dynamics, it shows that punitive damages create problematic risk arbitrage opportunities, which systemically produce under- and overvaluation of cases. These effects yield inefficient pricing in the litigation system. Properly conceptualized and applied, punitive damages can mitigate risk arbitrage that skews actual results from the prescriptions of optimal liability and deterrence. The modern Supreme Court jurisprudence is flawed because it is overbroad. Single-digit multiplier caps underdeter defendants in most cases of ordinary liability because punitive damages do not sufficiently offset a defendant's risk arbitrage opportunity gained from a lower litigation risk exposure. When liability is catastrophic, however, punitive damages overdeter defendants, even with a single-digit ratio limit, because they impart the severe economic cost of financial distress in addition to the monetary cost of the judgment. These additional economic costs must be credited toward the calculus of cost internalization and optimal deterrence. Thus, a calibrated risk-based theory is needed to support legal limitations on punitive damages.
\end{abstract}

\section{TABLE OF CONTENTS}

INTRODUCTION

I. The Central Problem of Punitive Damages ........................ 8

A. From Constitutional Reformation to Legal Uncertainty........ 8

B. Bursting the Myth and Identifying the Central Problem ..... 15

C. The Problem of Low Frequency, High Severity Awards ...... 17

II. LAW AND ECONOMics Theory AND CRitiQue..........................20

A. Standard Law and Economics Theory ............................... 20

* Marbury Research Professor of Law and Co-Director, Business Law Program, University of Maryland Francis King Carey School of Law. This Article was selected for presentation at the 2011 conferences of the Midwest Law and Economics Association, the Canadian Law and Economics Association, and the Italian Society of Law and Economics. I thank participants of these conferences, and also Bob Condlin, Don Gifford, Mark Graber, Simone Sepe, Jana Singer, and Max Stearns for their helpful comments. 
B. Critique of the Standard Theory 21

C. Toward a Complete Theory of Optimal Liability.................. 24

III. Risk Arbitrage in Settlements ............................................. 25

A. Corporations as Defendants.............................................. 25

B. Risk Arbitrage in Ordinary Cases ....................................... 27

C. Risk Arbitrage in Catastrophic Cases................................. 30

D. Case Studies of Texaco-Pennzoil and BP's Gulf Oil Spill ... 36

IV. Toward Optimal Liability and DeterRence ......................... 41

A. Arbitrage and Efficient Pricing ............................................ 41

B. Mitigating Risk Arbitrage in Ordinary Cases...................... 42

C. Mitigating Risk Arbitrage in Catastrophic Cases................ 44

D. The Role of Wealth and Administrative Issues..................... 49

V. REASSESSING GORE, CAMPBELL, WILLIAMS, AND BAKER .........51

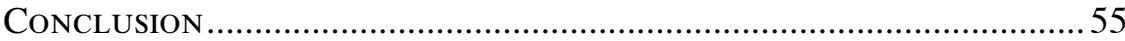

\section{INTRODUCTION}

In the course of fundamentally reshaping the law on punitive damages, ${ }^{1}$ the Supreme Court came to accept the rhetoric that punitive damages are "out of control.". 2 This view justified constraining punitive damage awards under the Due Process Clause of the Constitution in two landmark cases. In BMW of North America, Inc. v. Gore, the Court held that a 500x multiple of punitive to compensatory damages was a "grossly excessive award" that violated substantive due process. ${ }^{3}$ In State Farm Mutual Automobile Insurance Co. v. Campbell, the Court signaled that single-digit multipliers are more likely to satisfy due process. ${ }^{4}$

The move toward bright-line quantitative caps has been criticized as "theoretically bankrupt," "harmful," ${ }^{\circ}$ and "extremely crude." The Court has well earned this criticism since it has not explained why single-digit multipliers satisfy constitutional or theoretical concerns aside from relying on an unfounded perception that punitive damages have spiraled out of control. The decisions in Gore and Campbell sought to reduce systemically the

1. See Exxon Shipping Co. v. Baker, 554 U.S. 471 (2008); Philip Morris USA v. Williams, 549 U.S. 346 (2007); State Farm Mut. Auto. Ins. Co. v. Campbell, 538 U.S. 408 (2003); BMW of N. Am., Inc. v. Gore, 517 U.S. 559 (1996).

2. See, e.g., Browning-Ferris Indus. of Vt., Inc. v. Kelco Disposal, Inc., 492 U.S. 257, 282 (1989) (O'Connor, J., dissenting) (“Awards of punitive damages are skyrocketing.”).

3. 517 U.S. at $583,585-86$.

4. 538 U.S. at 425 .

5. Catherine M. Sharkey, The Exxon Valdez Litigation Marathon: A Window on Punitive Damages, 7 U. St. Thоmas L.J. 25, 28 (2009).

6. Keith N. Hylton, Punitive Damages and the Economic Theory of Penalties, 87 Geo. L.J. 421, 454 (1998).

7. Cass R. Sunstein, Daniel Kahneman \& David Schkade, Assessing Punitive Damages (with Notes on Cognition and Valuation in Law), 107 YALE L.J. 2071, 2126 (1998). 
amount of punitive damages in the tort system by imposing quantitative caps as a disciplinary measure on state laws and by imposing standards governing the permissibility of punitive awards.

However, the suggestion that tort law redistributes excessive amounts of wealth is a Potemkin village. ${ }^{8}$ In Exxon Shipping Co. v. Baker, the Supreme Court's latest decision on punitive damages, the Court finally rejected the fallacious premise behind its venture into the workings of state tort law: "A survey of the literature reveals that discretion to award punitive damages has not mass-produced runaway awards, and ... by most accounts the median ratio of punitive to compensatory awards has remained less than 1:1." Bursting the myths advanced by tort reformists, ${ }^{10}$ Baker concluded that the tort system has exercised "overall restraint."11

So what is the problem? According to Baker, the "real problem, it seems, is the stark unpredictability of punitive awards." 12 Although punitive damages are seldom awarded in tort cases and the median award is less than the median compensatory damages award, the variance in awards "is great, and the outlier cases subject defendants to punitive damages that dwarf the corresponding compensatories." ${ }^{13}$ Variance is a measure of the spread of potential economic outcomes. ${ }^{14}$ This spread is the essential quality of riskiness..$^{15}$ The greater the spread of potential outcomes, the greater the risk.

The core problem is not a systemic amount of punitive damages resulting in dramatic redistribution of wealth through the tort system. Rather, the problem is that "punitive damages are a substantial source of variance in the tort system-something that, in turn, increases the uncertainty over the ultimate parameters of the defendant's liability." 16 Such awards are like lightning: they rarely strike but when they do, the consequences are severe. The small but very real risk of an excessive award has significant ripple effects on the entire tort and civil dispute systems. The core problem in punitive damages is one of risk and uncertainty.

8. Sharkey, supra note 5, at 29 ("The ratio factor, moreover, may simply deflect attention from the fact that the constitutional edifice is, in effect, a house of cards.")

9. 554 U.S. at 497-98 (footnote omitted).

10. See Sharkey, supra note 5, at 36 ("The attack on punitive damages ... has been ... fueled by myriad organizations representing corporate and business interests."); see also Baker, 554 U.S. at $501 \mathrm{n} .17$ (citing studies).

11. Baker, 554 U.S. at 497-99.

12. Id. at 499 .

13. Id. at 500 .

14. Variance is the statistical mean squared deviation from the expected value, which is the risk of an expected return. Richard A. Brealey et al., Principles of Corporate FiNance 163 (10th ed. 2011); M.G. Bulmer, Principles of Statistics 56 (1979). As used in this Article, variance is used to connote the riskiness of an expected outcome as measured by the spread of potential outcomes.

15. See Robert J. Rhee, The Effect of Risk on Legal Valuation, 78 U. CoLo. L. REv. 193, 199 (2007) ("With zero variance, there is no risk as the expected result is certain.").

16. Richard A. Nagareda, Mass Torts in a World of Settlement 126 (2007). 
Scholarship on punitive damages has been copious and rich in both theoretical and empirical insights. ${ }^{17}$ As evinced by its influence on the Supreme Court, the empirical scholarship has shed light on facts and dispelled misconceptions about punitive damages. On the theory side, the inquiry has focused on the purpose of punitive damages. Courts have consistently asserted that punitive damages serve the twin goals of "retribution and deterring harmful conduct." 18 Scholars have advanced a broad array of theories principally coalescing around these two basic ideas. ${ }^{19}$ Law and economics theory has led the way in establishing a coherent view of deterrence. ${ }^{20}$ The theory has garnered a "remarkable consensus" among a wide range of scholars that deterrence is a central goal of punitive damages. ${ }^{21}$

17. See Cass R. Sunstein et al., Punitive Damages (2002); Steve P. Calandrillo, Penalizing Punitive Damages: Why the Supreme Court Needs a Lesson in Law and Economics, 78 Geo. Wash. L. Rev. 774 (2010); Thomas B. Colby, Clearing the Smoke from Philip Morris v. Williams: The Past, Present, and Future of Punitive Damages, 118 Yale L.J. 392 (2008); Robert D. Cooter, Economic Analysis of Punitive Damages, 56 S. CaL. L. Rev. 79 (1982); Marc Galanter \& David Luban, Poetic Justice: Punitive Damages and Legal Pluralism, 42 Am. U. L. Rev. 1393 (1993); Dan Markel, How Should Punitive Damages Work?, 157 U. PA. L. Rev. 1383 (2009); Dan Markel, Retributive Damages: A Theory of Punitive Damages as Intermediate Sanction, 94 CoRnell L. Rev. 239 (2009); A. Mitchell Polinsky \& Steven Shavell, Punitive Damages: An Economic Analysis, 111 Harv. L. Rev. 869 (1998); Anthony J. Sebok, Punitive Damages: From Myth to Theory, 92 Iowa L. Rev. 957 (2007); Catherine M. Sharkey, Punitive Damages as Societal Damages, 113 Yale L.J. 347 (2003); Sunstein, Kahneman \& Schkade, supra note 7; W. Kip Viscusi, The Social Costs of Punitive Damages Against Corporations in Environmental and Safety Torts, 87 Geo. L.J. 285 (1998); Benjamin C. Zipursky, A Theory of Punitive Damages, 84 Tex. L. Rev. 105 (2005).

In the field of empirical scholarship, one camp has argued that punitive damages are out of control. See Alison F. Del Rossi \& W. Kip Viscusi, The Changing Landscape of Blockbuster Punitive Damages Awards, 12 Am. L. \& Econ. Rev. 116, 154-55 (2010); Joni Hersch \& W. Kip Viscusi, Punitive Damages: How Judges and Juries Perform, 33 J. Legal Stud. 1, 9 (2004). Another camp of empiricists has argued that punitive damages are reasonable and predictable. See Theodore Eisenberg et al., Juries, Judges, and Punitive Damages: An Empirical Study, 87 Connell L. Rev. 743, 745 (2002) [hereinafter Eisenberg et al. 2002]; Theodore Eisenberg et al., Juries, Judges, and Punitive Damages: Empirical Analyses Using the Civil Justice Survey of State Courts 1992, 1996 and 2001 Data, 3 J. Empirical Legal Stud. 263, 270 (2006) [hereinafter Eisenberg et al. 2006]; Theodore Eisenberg et al., The Predictability of Punitive Damages, 26 J. Legal Stud. 623, 624-625 (1997) [hereinafter Eisenberg et al. 1997]; Theodore Eisenberg \& Martin T. Wells, The Significant Association Between Punitive and Compensatory Damages in Blockbuster Cases: A Methodological Primer, 3 J. EMPIRICAL Legal Stud. 175, 194 (2006); Theodore Eisenberg et al., Variability in Punitive Damages: Empirically Assessing Exxon Shipping Co. v. Baker, 166 J. Institutional \& Theoretical ECON. 5, 20 (2010) [hereinafter Eisenberg et al. 2010]; Neil Vidmar \& Mary R. Rose, Punitive Damages by Juries in Florida: In Terrorem and in Reality, 38 HARv. J. ON LEGIS. 487 (2001).

18. Baker, 554 U.S. at 492; BMW of N. Am., Inc. v. Gore, 517 U.S. 559, 568 (1996); Sharkey, supra note 17, at 356-57; see also Restatement (SECOND) of Torts $§ 908(1)$ (1965).

19. Compare Polinsky \& Shavell, supra note 17 (arguing for deterrence), with Sebok, supra note 17 (arguing for private retribution).

20. See Polinsky \& Shavell, supra note 17 , at $889-90$.

21. Sebok, supra note 17, at 982 . 
The standard law and economics theory argues that punitive damages should be imposed on defendants who would otherwise escape liability through undetected wrongful acts. ${ }^{22}$ This concept yields an elegant formula for calculating punitive damages: punitive damages should equal the harm multiplied by the reciprocal of the injurer's chance of being found liable for wrongful activities. ${ }^{23}$ Based on this theory, punitive damages should provide a level of liability sufficient to achieve full cost internalization and optimal deterrence. Despite the elegance of the idea, the standard law and economics theory fails to account for the central problem of punitive damages identified by the Supreme Court and other scholars-the relationship between the risk associated with high variance outcomes and the theory of punitive damages. On this issue, the Court has suggested that it would be open to accepting variance as a desirable effect if variance promoted an "optimal level of penalty and deterrence," but there is neither empirical evidence nor theory explaining the role of variance or how it should be used. ${ }^{24}$ This Article provides a theory of variance.

Consistent with law and economics thought, the premise of this Article is that tort law should deter wrongful conduct by imposing an optimal level of liability. However, undetected wrongful conduct, the key point of the standard law and economics model, is not the principal problem. The essential problem concerns the relationship between the riskiness of punitive damages and the deterrence effect of punitive damages. A complete theory requires a financial economic analysis to determine the effect of risk on the valuation of uncertain future cash flows ${ }^{25}$-in the legal and dispute resolution contexts, the effect of risk on the valuation of disputed legal rights. Yet no scholar has undertaken a financial economic analysis of punitive damages.

A nascent but growing body of scholarship has applied principles of financial economics to model the civil litigation system. ${ }^{26}$ This work suggests that civil litigation for money damages, such as tort cases, fundamentally boils down to assigning financial values to a disputed right, analogous to how rights to uncertain future cash flows associated with securities instru-

22. Calandrillo, supra note 17, at 799; Polinsky \& Shavell, supra note 17, at 874 .

23. Polinsky \& Shavell, supra note 17 , at 889.

24. Exxon Shipping Co. v. Baker, 554 U.S. 471, 500 (2008).

25. Stephen A. Ross, Neoclassical Finance 1 (2005).

26. See Joseph A. Grundfest \& Peter H. Huang, The Unexpected Value of Litigation: A Real Options Perspective, 58 Stan. L. Rev. 1267 (2006); Jonathan T. Molot, Litigation Finance: A Market Solution to a Procedural Problem, 99 Geo. L.J. 65 (2010); Jonathan T. Molot, A Market in Litigation Risk, 76 U. CHI. L. Rev. 367 (2009); Richard A. Nagareda, Autonomy, Peace, and Put Options in the Mass Tort Class Action, 115 Harv. L. Rev. 747 (2002); Rhee, supra note 15; Robert J. Rhee, A Price Theory of Legal Bargaining: An Inquiry into the Selection of Settlement and Litigation Under Uncertainty, 56 EMORY L.J. 619, 623 (2006) [hereinafter Rhee, Price Theory of Legal Bargaining]; Robert J. Rhee, Toward Procedural Optionality: Private Ordering of Public Adjudication, 84 N.Y.U. L. Rev. 514 (2009) [hereinafter Rhee, Toward Procedural Optionality]. 
ments and capital assets are valued in the financial markets. ${ }^{27}$ Commenting on the recent insights provided by a finance perspective, Professor Richard Nagareda has observed that finance-based models of litigation behavior complement the cognitive psychology models of the civil justice system:

Risk matters not just in the sense of whether a given party faces a potential gain or loss in the endgame of litigation. From a finance-based standpoint, risk also matters in the sense that a given party might stand to bear or to impose risk itself in the form of variance. ${ }^{28}$

Risk is important to an understanding of the litigation and tort systems, and a theory of punitive damages should account for it. Drawing on recent insights from the finance perspective of litigation, this Article advances an alternative deterrence-based theory.

Viewed from this perspective, the modern Supreme Court reformation of punitive damages is wrong. With optimal deterrence as one normative end, the prescriptions in Gore and Campbell are overbroad, underdeterring in some circumstances and overdeterring in others. Central to this thesis is the problem of settlement. Punitive damages affect not only the small class of cases most likely to be candidates for punitive awards, but they also have significant ripple effects on the settlement side of the tort system. These ripple effects are not visible through analysis of case law. Although scholars have suggested a "shadow effect" on settlement, ${ }^{29}$ with some suggesting that punitive damages increase settlement values, ${ }^{30}$ no scholar has advanced an economic theory that integrates settlement into the calculus of optimal deterrence.

This Article advances an arbitrage theory of the relationship among variance, punitive damages, and settlement. ${ }^{31}$ In financial markets, arbitrage is

27. Rhee, supra note 15, at 193; Rhee, Toward Procedural Optionality, supra note 26, at 534 .

28. Richard A. Nagareda, 1938 All Over Again? Pretrial as Trial in Complex Litigation, 60 DePaul L. Rev. 647, 660 (2011).

29. Thomas Koenig, The Shadow Effect of Punitive Damages on Settlements, 1998 Wis. L. Rev. 169, 172 (1998); Sebok, supra note 17, at 965; see also Thomas A. Eaton, David B. Mustard \& Susette M. Talarico, The Effects of Seeking Punitive Damages on the Processing of Tort Claims, 34 J. Legal Stud. 343, 353-34, 357 (2005); Herbert M. Kritzer \& Frances Kahn Zemans, The Shadow of Punitives: An Unsuccessful Effort To Bring It into View, 1998 WIs. L. Rev. 157, 166 (1998); A. Mitchell Polinsky, Are Punitive Damages Really Insignificant, Predictable, and Rational? A Comment on Eisenberg et al., 26 J. Legal Stud. 663, 665 (1997).

30. See George L. Priest, Punitive Damages Reform: The Case of Alabama, 56 LA. L. Rev. 825, 830 (1996); Viscusi, supra note 17, at 326-27.

31. I make three caveats that limit the scope of the inquiry here. First, this Article is not about the retribution theory, its relationship to the deterrence goal, or whether one or the other is the predominant policy in punitive damages. Second, this Article is not about how the rules prescribed here can be molded to a constitutional theory of punitive damages, if there is one. Third, the economic concept of severe liability and its effect on corporate finance applies to other areas of tort law, specifically mass torts and class actions. These issues are related because they share the essential attribute of catastrophic legal risk. But these areas of law also significantly differ: the principal difference being that financial distress is irrelevant in mass 
the process of making an abnormal profit by buying assets in one market and selling them in another, or vice versa, to profit from an unjustified price difference. ${ }^{32}$ Sustained or systematic arbitrage opportunities evince inefficiencies in market pricing. As used here, the term "arbitrage" connotes the concept that a class of litigants can systematically enjoy advantages during settlement due to consistent, predictable, and recurring circumstances, resulting in aggregate settlement values that deviate from expected judicial outcomes. While in an individual case a party's unique advantage is understood in the lexicon of bargaining as "leverage," ${ }^{33}$ arbitrage is a more apt term here because it communicates the idea of prices deviating from intrinsic values across the tort system and accordingly affecting the system's efficiency.

This Article shows that risk imposes significant economic costs that are borne by both parties to a litigation under different circumstances. Financial economics tell us that risk has a price. Investors must be paid to bear risk; the greater the risk, the more they must be compensated. ${ }^{34}$ The nature of litigation requires that parties be risk bearers, and their exposure to litigation risks is different depending on whether the risk is ordinary or severe. In most circumstances where the potential liability is ordinary, a corporate defendant has a lower exposure to litigation risk than an individual plaintiff and thus enjoys a systemic risk arbitrage opportunity resulting from repeated valuational concessions at settlement by plaintiffs under a set of recurring conditions. ${ }^{35}$ This settlement effect tends to undervalue cases from the perspective of optimal liability. However, when a corporate defendant is exposed to catastrophic risk - low frequency, high severity awards - the risk arbitrage flips to a systematic advantage for plaintiffs. The defendant will pay a risk premium to eliminate the risk through settlement. This settlement effect tends to overvalue cases. Unlike the standard law and economics theory of punitive damages, which focuses on using punitive damages to correct escaped liability, this Article argues that optimal deterrence is best achieved by using punitive damages to mitigate these mutual risk arbitrage opportunities. This Article provides a financial model of these effects per principles of corporate finance valuation, premium underwriting, and capital budgeting. When the principal defendants at issue are corporations, a theory of punitive damages must account for the implications on corporate finance and risk transfer.

torts and class actions because compensation is mandatory upon proof of liability, whereas punitive damages are discretionary awards.

32. Randall S. Billingsley, Understanding Arbitrage (2006).

33. See Robert H. Mnookin \& Robert B. Wilson, Rational Bargaining and Market Efficiency: Understanding Pennzoil v. Texaco, 75 VA. L. Rev. 295, 299 (1989) (defining "leverage" as a means "to extract a more favorable settlement").

34. See Harry Markowitz, Portfolio Selection, 7 J. Fin. 77, 77 (1952) (“[T]he investor does (or should) consider expected return a desirable thing and variance of return an undesirable thing." (emphasis omitted)).

35. Robert J. Rhee, Tort Arbitrage, 60 Fla. L. Rev. 125, 181 (2008). 
This analysis yields simple prescriptive rules for regulating punitive damages: (1) when punitive damages do not threaten financial distress, ${ }^{36}$ there should be no regulation of punitive damages outside of traditional, preexisting state law protections against excess and abuse; (2) the cap on punitive damages should not be some arbitrary cap based on a numeric ratio, but it should instead be a function of the defendant's wealth such that punitive damages are limited to the point at which the defendant would experience financial distress. For the vast majority of tort cases, financial distress is not an issue, and in these cases the pre-Gore jurisprudence best promotes optimal deterrence. Even a minute probabilistic threat of high multiple and/or dollar value awards tends to offset a corporate defendant's risk arbitrage in settlement; accordingly, not capping punitive damages increases settlement values, achieving valuations closer to expected judicial outcomes. However, the economic costs associated with the financial distress generally impart greater social cost than any adverse incentives arising from inadequate liability assessment due to escaped liability. ${ }^{37}$ The limit of punitive damages can be defined as the maximum imposable residual liability net of compensatory damages and the financial economic costs on the firm associated with the litigation risk.

This Article is organized into five Parts. Part I provides an overview of the law and frames the central problem in this area of law. Part II summarizes the standard law and economics theory of punitive damages and then critiques this theory from the perspective of achieving optimal deterrence. Part III provides a financial economic model of how parties settle cases and shows why plaintiffs and defendants have different risk arbitrage opportunities during settlement depending on the circumstances and the nature of the risks each party confronts. Part IV argues that optimal deterrence is achieved only when the prices of legal actions are efficient and there are no arbitrage opportunities at settlement. It then relates this principle to the proper rules for regulating punitive damages. Lastly, Part V applies the theory of variance and risk arbitrage advanced here to reassess the Supreme Court's reformation of punitive damages.

\section{The Central Problem of Punitive Damages}

\section{A. From Constitutional Reformation to Legal Uncertainty}

Although punitive damages are well established in American tort law, ${ }^{38}$ the Supreme Court has undertaken a major reformation of punitive damages

36. Financial distress is defined as substantial disruptions in a firm's ordinary operations resulting from a severe financial loss. It has significant economic consequences. See infra Section III.C.

37. See infra Section III.C (discussing the economic costs of financial distress).

38. See Exxon Shipping Co. v. Baker, 554 U.S. 471, 490-91 (2008) (citing Boyd v. United States, 116 U.S. 616, 626 (1886); Day v. Woodworth, 54 U.S. (13 How.) 363, 371 (1852) (punitive damages had "become widely accepted in American courts by the middle of the 19th century"). 
jurisprudence over the past twenty years, which has resulted in significant constitutional restrictions on punitive damages awards. I provide a brief review of the case law to focus specifically on the multipliers in the cases and to provide a sense of the positions of individual Justices.

In Browning-Ferris Industries of Vermont, Inc. v. Kelco Disposal, Inc., the Court addressed the issue of whether the Eighth Amendment applies to punitive damages..$^{39}$ The case arose out of the defendant's attempt to drive the plaintiff out of a local disposal business through illegal price-fixing and tortious interference with contracts. ${ }^{40}$ The jury awarded compensatory damages of $\$ 51,146$ and punitive damages of $\$ 6$ million. ${ }^{41}$ The Court, per Justice Blackmun, held that the Eighth Amendment does not apply to civil actions when the government is not a party. ${ }^{42}$

Justice O'Connor, concurring in part and dissenting in part, argued that corporations should be given Eighth Amendment protection against the threat of "overbearing and oppressive monetary sanctions." ${ }^{43}$ She introduced the germ of the idea of a quantitative standard. The multiple of punitive to compensatory damages was $117 \mathrm{x}$, far exceeding the highest reported award of punitive damages in the state, and she implied that a multiple of $30 \mathrm{x}$ should be considered suspect. ${ }^{44}$ She also suggested that the imposition of punitive damages could violate due process, a position that three other Justices shared. ${ }^{45}$

In Pacific Mutual Life Insurance Co. v. Haslip, the Court, per Justice Blackmun, considered whether the Fourteenth Amendment applies to punitive damages. ${ }^{46}$ The defendant insurance company was held liable for punitive damages under the theory of respondeat superior when its employee-agent embezzled the plaintiff's premium money and allowed the policy to lapse. The plaintiff was awarded $\$ 1,040,000$, of which $\$ 200,000$ was apparently compensatory, including $\$ 4,000$ in out-of-pocket expenses. ${ }^{47}$ The Court approved the punitive damages award, a multiple of $4 \mathrm{x} .{ }^{48} \mathrm{It}$ declined to "draw a mathematical bright line" and instead suggested that

39. 492 U.S. 257, 260 (1989).

40. Browning-Ferris, 492 U.S. at 260-61.

41. Id. at 262 .

42. Id. at $263-64$.

43. Id. at 285 (O'Connor, J., concurring in part and dissenting in part) (joined by Justice Stevens).

44. Id. at 282 .

45. Id. at 283. Justices Brennan and Marshall concurred specially to make this point. Id. at 280-81 (Brennan, J., concurring) (joined by Justice Marshall). With Justices O'Connor and Stevens, four Justices opined that the Due Process Clause applies to awards of punitive damages.

46. 499 U.S. 1, 4 (1991).

47. Haslip, 499 U.S. at $6,7 \&$ n.2.

48. Id. at $23-24$. 
the appropriate constitutional calculus is one of "general concerns of reasonableness." 49

Justice Scalia concurred to reject the idea of substantive due process review for punitive damages. ${ }^{50}$ Justice Kennedy concurred to opine that a lack of uniformity in punitive damages cannot be equated to constitutional infirmity since variance in outcomes is the nature of civil litigation in general, and that the usual protections given by states must suffice until common law judges or legislatures initiate systemic changes. ${ }^{51}$ Justice O'Connor was the sole dissenter. Describing punitive damages as a "powerful weapon," ${ }^{52}$ she argued for a reevaluation of punitive damages, contending that there had been an explosion in the frequency and size of punitive awards and that juries were not constrained in their discretion. ${ }^{53}$

In TXO Production Corp. v. Alliance Resources Corp., the Court addressed whether a punitive damages award of $\$ 10$ million on top of compensatory damages of $\$ 19,000$, a multiple of $526 x$, violated due process. ${ }^{54}$ The Court upheld the judgment but was split as to reasoning. Relying on Haslip, the plurality Court, per Justice Stevens, declined to draw mathematical bright lines. ${ }^{55}$ The high multiple was not controlling in this case in light of the large amount of money at stake, the defendant's bad faith, a larger pattern of fraud and deceit, and the defendant's wealth. ${ }^{56}$ The Court also noted that the "shock dissipates when one considers the potential loss" to the plaintiff of $\$ 1$ million, a punitive damages multiple of only 10x..$^{57}$ Justices Scalia concurred to opine that the Court should "shut the door" on the idea of a substantive due process right to be free of excessive punitive damages ${ }^{58} \mathrm{He}$ predicted the following: "The plurality's decision is valuable, then, in that the great majority of due process challenges to punitive damages awards can henceforth be disposed of simply with the observation that 'this is no worse than TXO.' "59 This prophecy was ultimately proven wrong as the Court continued to delve into the jurisprudence of punitive damages.

In the next case, the landmark decision of BMW of North America, Inc. v. Gore, the Court for the first time invalidated a punitive damages award under the Due Process Clause. ${ }^{60}$ The facts are well known. A national car dealership sold a car as new when it had been repaired; at trial, the actual

49. Id. at 18 .

50. Id. at 25, 28 (Scalia, J., concurring in the judgment).

51. Id. at 41-42 (Kennedy, J., concurring in the judgment).

52. Id. at 42 (O'Connor, J., dissenting).

53. Id. at $61-63$

54. 509 U.S. 443, 446 (1993).

55. TXO, 509 at $458,460,462$.

56. Id. at 462 .

57. Id. While the compensatory award was $\$ 19,000$, the Court noted that the potential harm to the plaintiff could have been in the range of \$1-\$4 million. Id.

58. Id. at 470,472 .

59. Id.

60. 517 U.S. 559 (1996). 
damages were $\$ 4,000$ and the jury awarded punitive damages of $\$ 4$ million (later reduced on appeal to $\$ 2$ million). ${ }^{61}$ The issue was whether the $500 \mathrm{x}$ multiple comported with due process. The Court, per Justice Stevens, set forth a legal standard composing of three guideposts: (1) the degree of reprehensibility, (2) the disparity between the harm and the punitive damages, and (3) the difference between the punitive damages and the civil penalties imposed or authorized in other cases. ${ }^{62}$ Applying these factors, the Court determined that the conduct was not so reprehensible, considering that the harm was "purely economic in nature" and involved an omission of fact that may have had a good-faith basis. ${ }^{63}$ The Court considered the $4 \mathrm{x}$ multiple in Haslip and the 10x multiple to the potential harm in TXO and determined that "a breathtaking 500 to 1 " ratio is constitutionally infirm. ${ }^{64}$

Gore was a close case. Justices Scalia and Thomas dissented on the now-familiar objection to substantive due process review and dismissed the three guideposts as "a road to nowhere." ${ }^{55}$ Justices Ginsburg and Rehnquist also dissented but on the grounds that states have an interest in punishment and deterrence, that the procedure satisfied due process, and that the Court was unwisely venturing into the realm of state law. ${ }^{66}$

In State Farm Mutual Automobile Insurance Co. v. Campbell, the Court further strengthened the constraints on punitive damages. ${ }^{67}$ In an action for insurance bad faith arising out of the insurer's failure to settle a third-party liability claim, the jury awarded $\$ 1$ million in compensatory damages and $\$ 145$ million in punitive damages. ${ }^{68}$ The Court, per Justice Kennedy, applied Gore's three guideposts. ${ }^{69}$ Additionally, the Court famously laid down a quantitative marker: "Our jurisprudence and the principles it has now established demonstrate, however, that, in practice, few awards exceeding a single-digit ratio between punitive and compensatory damages, to a significant degree, will satisfy due process." ${ }^{70}$ Based largely on the fact that the multiple at issue was $145 \mathrm{x}$, the Court struck down the award. ${ }^{71}$

In Philip Morris USA v. Williams, the plaintiff argued that the defendant cigarette manufacturer knowingly and falsely led him to believe that smoking was safe. ${ }^{72}$ The jury awarded compensatory damages of $\$ 821,000$ and

61. Gore, 517 U.S. at 563-67.

62. Id. at 575 .

63. Id. at $575-80$.

64. Id. at 581-83.

65. Id. at 598-607.

66. Id. at 607-19.

67. 538 U.S. 408 (2003).

68. Campbell, 538 U.S. at 412-15.

69. Id. at 418-28.

70. Id. at 425 .

71. Id. at 429. Justices Scalia, Thomas, and Ginsburg dissented along similar lines of reasoning as expressed in their dissents in Gore. Id. at 429 (Scalia, J., dissenting); id. at 42930 (Thomas, J., dissenting); id. at 30-39 (Ginsburg, J., dissenting).

72. 549 U.S. $346,349-50$ (2007). 
punitive damages of $\$ 79.5$ million, a multiple of $96.8 \mathrm{x}$. Notably, Williams is the only case in the line from Browning-Ferris to Campbell that involved personal injuries. ${ }^{73}$ The Court chose not to consider whether this award was grossly excessive. ${ }^{74}$ Instead, it focused on whether punitive damages can be based in part on a jury's desire to punish the defendant for harming nonparty victims. This issue - punitive damages based in part on broader harm to others arising from similar activities-was also present in Gore and Campbell. ${ }^{75}$ The Williams Court, per Justice Breyer, directly addressed the issue and held that a jury may not punish a defendant for harms caused to others but that it may consider such conduct in determining reprehensibility. ${ }^{76}$

The constitutional journey into the jurisprudence of punitive damages took a detour into federal maritime law with Exxon Shipping Co. v. Baker. ${ }^{77}$ The case arose out of the 1989 oil spill in the Prince William Sound where Exxon's ship ran aground. On claims brought by commercial fishermen for lost profit, ${ }^{78}$ the jury awarded $\$ 287$ million in compensatory damages and punitive damages of $\$ 5$ billion (later remitted to $\$ 2.5$ billion). The issue was whether federal maritime law constrains punitive damages. The Court, per Justice Souter, was skeptical that verbal formulations could work to promote "systemic consistency." " Looking to the median multiple of punitive damages (cited as $0.65 \mathrm{x}$ based on empirical scholarly studies), the Court set a $1: 1$ ratio cap on punitive damages in maritime cases. ${ }^{80}$

Three prominent themes can be seen in the line of cases from Browning-Ferris to Baker. The first theme is obvious but worth mentioning. The Supreme Court increasingly lost confidence in state process and juries ${ }^{81}$ The earlier cases exhibit a reluctance to actively review lower court decisions. Justice O'Connor speculated that the Court's early reticence stemmed from not wanting to open the door to wholesale review of state tort law

73. Cf. Campbell, 538 U.S. at 426 ("The harm arose from a transaction in the economic realm, not from some physical assault or trauma ...."); BMW of N. Am., Inc. v. Gore, 517 U.S. 559, 576 (1996) ("The harm BMW inflicted on Dr. Gore was purely economic in nature.”).

74. Williams, 549 U.S. at 353.

75. Campbell, 538 U.S. at 420, 422-23; Gore, 517 U.S. at 568-74; id. at 608 (Ginsburg, J., dissenting).

76. Williams, 549 U.S. at 356-57. Justices Stevens, Scalia, Thomas, and Ginsburg dissented.

77. 554 U.S. 471 (2008).

78. Baker, 554 U.S. at 476. For a discussion of the rights of fishermen to recover for lost profit, see Robert J. Rhee, A Production Theory of Pure Economic Loss, 104 Nw. U. L. Rev. 49, 54-60, 94-103 (2010).

79. Baker, 554 U.S. at 504.

80. Id. at 513. Justices Stevens, Ginsburg, and Breyer concurred in part and dissented in part.

81. See Pac. Mut. Life Ins. Co. v. Haslip, 499 U.S. 1, 63 (1991) (O'Connor, J., dissenting) ("When we lose that confidence [in fair and reasonable results], a change must be made."). 
practices. ${ }^{82}$ But that reticence was overcome by the time the Court decided Gore, a case in which the Court substituted its judgment on the degree of egregiousness - ordinarily the fact finder's prerogative-to strike down the award ${ }^{83}$ Gore, Campbell, and Baker exhibit an activist approach of reviewing and superseding state judgments on matters of evidentiary weight and implementation of state policy. ${ }^{84}$

The second theme is the most notable - a move away from a qualitative, multifactor standard to a rule-based numerical cap. ${ }^{85}$ In Haslip, the Court declined to "draw a mathematical bright line." ${ }^{86}$ This principle was later repeated in TXO, Gore, and Campbell, ${ }^{87}$ but the professed rejection of hard-and-fast numeric caps in Campbell seems inconsistent when in the same paragraph the Court wrote "[s]ingle-digit multipliers are more likely to comport with due process." 88 Justice Kennedy, who authored Campbell, seems to have been the bellwether for this shift in the Court's thinking as he was the only Justice to have reversed his earlier position on numerical caps. ${ }^{89}$ The analytic framework of a numerical cap is seen in Baker, which rejected a qualitative standard in favor of a bright-line $1 \mathrm{x}$ multiple limit. ${ }^{90}$ Although Baker is a maritime case, the influence of its support for numerical caps and its policy rationale extend beyond its subject-matter jurisdiction. $^{91}$

The third theme is a link among punitive damages, corporate interests, and economic policy. Through all of the punitive damages cases, the Court advanced a pro-business economic agenda by protecting corporations from excessive liability. All of the cases from Browning-Ferris to Baker involved large national corporations. ${ }^{92}$ That corporations were the principal defend-

82. See id. at 64 .

83. BMW of N. Am., Inc. v. Gore, 517 U.S. 559, 585-86 (1996); id. at 612 (Ginsburg, J., dissenting).

84. Michael P. Allen, The Supreme Court, Punitive Damages and State Sovereignty, 13 Geo. Mason L. Rev. 1, 10 (2004).

85. The Court has repeatedly asserted that reprehensibility is the most significant guidepost. State Farm Mut. Auto. Ins. Co. v. Campbell, 538 U.S. 408, 419 (2003); Gore, 517 U.S. at 575. But the quantitative cap has become the important factor. Sharkey, supra note 5, at $27-28$.

86. Haslip, 499 U.S. at 18.

87. Campbell, 538 U.S. at 424-25; Gore, 517 U.S. at 582-83; TXO Prod. Corp. v. Alliance Res. Corp., 509 U.S. 443, 458 (1993).

88. Campbell, 538 U.S. at 425.

89. "The Constitution identifies no particular multiple of compensatory damages as an acceptable limit for punitive awards; it does not concern itself with the dollar amounts, ratios, or the quirks of juries in specific jurisdictions.” TXO, 509 U.S. at 467 (Kennedy, J., concurring).

90. Exxon Shipping Co. v. Baker, 554 U.S. 471, 504 (2008).

91. See, e.g., Hayduk v. City of Johnstown, 580 F. Supp. 2d 429, 483 n.46 (W.D. Pa. 2008) (noting that Baker has "a much broader application").

92. Philip Morris, State Farm, Exxon, BMW, and Pacific Mutual Life are well known. The defendants in Browning-Ferris and TXO were also national companies. TXO, 509 U.S. at 450 n.9; Browning-Ferris Indus. of Vt., Inc. v. Kelco Disposal, Inc., 492 U.S. 257, 260 (1989). 
ants raises two economic issues. The Court feared that punitive damages could give juries the power to improperly redistribute the wealth stored in corporations. ${ }^{93}$ And, in a line of thinking developed in the later cases, the Court feared that the principle of federalism could be undermined when state tort law conflicts with interstate commerce and the national economy. ${ }^{94}$

The line of cases from Browning-Ferris to Baker spanned nineteen years and involved fifteen Justices. Several Justices have been influential beyond their single vote. Justice O'Connor has been the most vocal critic of punitive damages and advocate of strict constraints, and her forceful dissents in Browning-Ferris, Haslip, and TXO may have influenced her colleagues and the Court's later thinking. Justice Stevens authored the plurality opinion in TXO and the majority opinion in Gore. Justices Kennedy, Breyer, and Souter authored respectively the majority opinions in Campbell, Williams, and Baker. Justices Kennedy and Breyer still sit on the Court today, and both have voted in favor of constitutional constraints. Chief Justice Roberts voted with the majority in Williams and Baker, and Justice Alito did the same in Williams. Justices Scalia and Thomas have opposed the idea of substantive due process limitations on punitive damages. Justice Ginsburg dissented in Gore, Campbell, Williams, and Baker, and she opposes the Court's application, if not the theory, of constitutional constraint.

We do not know whether the law has been shaped into its final form by Gore, Campbell, Williams, and Baker, or whether it will continue to evolve into greater restrictions or even reverse course. Five members of the current Court-Justices Kennedy, Breyer, Scalia, Ginsburg, and Thomas-have staked out well-articulated positions on the issue. Scalia, Thomas, and Ginsburg disfavor constitutional scrutiny, perhaps for different reasons. Four Justices are relative newcomers to the debate: the Chief Justice and Justices Alito, Sotomayor, and Kagan. Chief Justice Roberts and Justice Alito likely favor constraints on punitive damages per their political and pro-business inclinations, ${ }^{95}$ an educated guess supported by their respective votes in Williams and Baker. If we assume that Justices Scalia and Thomas continue to believe that the application of substantive due process to punitive damages is wrong and that they will vote based on their core beliefs despite whatever pro-business leanings they may have, the tally is 4 to 3 in favor to continuing the current trajectory of the law. Justices Sotomayor and Kagan, who joined the Court after Baker, are the unknown factors, and they will be the swing voters in future cases.

93. See TXO, 509 U.S. at 490-91 (O’Connor, J., dissenting).

94. See Philip Morris USA v. Williams, 549 U.S. 346, 355 (2007); State Farm Mut. Auto Ins. Co. v. Campbell, 538 U.S. 408, 421-22 (2003); BMW of N. Am., Inc. v. Gore, 517 U.S. 559, 571 (1996); see also Samuel Issacharoff \& Catherine M. Sharkey, Backdoor Federalization, 53 UCLA L. Rev. 1353 (2006); Sharkey, supra note 5, at 30-31.

95. Since 1953, Justices Alito, Roberts, Thomas, and Scalia are in the top-ten list of Justices with the most pro-business bias. See Lee Epstein, William M. Landes \& Richard A. Posner, Is the Roberts Court Pro-Business? 2, 4 (Dec. 17, 2010) (unpublished study), available at http://epstein.usc.edu/research/RobertsBusiness.pdf. Among active Justices, Alito and Roberts are the most pro-business. See id. at 12-13. 
In addition to changing judicial composition, a theoretical deficit creates uncertainty about the future direction of the law. The Court has not articulated a theory of punitive damages. There is little justification for why it is "unfair" or "arbitrary" or "excessive" to impose punitive damages beyond the assertion that a single-digit multiplier is the limit. Absent a theory with analytic rigor, these characterizations are simply labels attached to a vote. The Court recognizes the common formulation that punitive damages serve the goals of deterrence and retribution. ${ }^{96}$ But it has not developed a theory of how retribution and deterrence are served by judicially capping punitive damages. Several Justices have been dismissive of economic analysis, ${ }^{97}$ which is odd since that body of scholarship has developed the most sophisticated analysis of deterrence theory.

The current Court composition and the theoretical deficit in the judicial literature have created uncertainty as to the future direction of punitive damages jurisprudence. Justice Kennedy is frequently considered the "swing vote," but in this area Justices Sotomayor and Kagan will play a crucial role in the development of the law. The Court "is in the midst of a major reexamination of punitive damages - the final chapter of which has not yet been written." ${ }^{98}$ At the same time, there is a crisis in the theory of punitive damages. ${ }^{99}$

\section{B. Bursting the Myth and Identifying the Central Problem}

The Supreme Court case law on punitive damages is commonly seen as being driven by a concern regarding "grossly excessive" punitive damages in the tort system. However, the perception that punitive damages have run amok is empirically false and has been disavowed. In Baker, the Court examined for the first time the well-developed empirical scholarship on punitive damages and concluded that there is no systemic problem with respect to aggregate liability amount. The Court's opinion not only disavowed a major assertion of the problem, but also much of the rhetoric that accompanied it. Two sweeping paragraphs of the opinion are important:

American punitive damages have been the target of audible criticism in recent decades, but the most recent studies tend to undercut much of it. A survey of the literature reveals that discretion to award punitive damages

96. Exxon Shipping Co. v. Baker, 554 U.S. 471, 492 (2008); Campbell, 538 U.S. at 416; Cooper Indus., Inc. v. Leatherman Tool Grp., Inc., 532 U.S. 424, 432 (2001); Gore, 517 U.S. at 568; Pac. Mut. Life Ins. Co. v. Haslip, 499 U.S. 1, 19 (1991).

97. See Browning-Ferris, 492 U.S. at 300 (O'Connor, J., concurring in part and dissenting in part) (joined by Justice Stevens) ("[T]he Eighth Amendment does not incorporate the views of the Law and Economics School."); TXO, 509 U.S. at 491-92 (O'Connor, J., dissenting) (joined by Justices White and Souter) (noting that the Fourteenth Amendment "does not require us to adopt the views of the Law and Economics school"); cf. Cooper, 532 U.S. at 439 (noting that "deterrence is not the only purpose served by punitive damages").

98. Sebok, supra note 17, at 959.

99. Id. at 960; see also Zipursky, supra note 17, at 105-06 (noting the "constitutional puzzle" created by Gore and its progeny). 
has not mass-produced runaway awards, and although some studies show the dollar amounts of punitive-damages awards growing over time, even in real terms, by most accounts the median ratio of punitive to compensatory awards has remained less than 1:1. Nor do the data substantiate a marked increase in the percentage of cases with punitive awards over the past several decades. The figures thus show an overall restraint and suggest that in many instances a high ratio of punitive to compensatory damages is substantially greater than necessary to punish or deter.

The real problem, it seems, is the stark unpredictability of punitive awards. Courts of law are concerned with fairness as consistency, and evidence that the median ratio of punitive to compensatory awards falls within a reasonable zone, or that punitive awards are infrequent, fails to tell us whether the spread between high and low individual awards is acceptable. The available data suggest it is not. A recent comprehensive study of punitive damages awarded by juries in state civil trials found a median ratio of punitive to compensatory awards of just $0.62: 1$, but a mean ratio of $2.90: 1$ and a standard deviation of 13.81. Even to those of us unsophisticated in statistics, the thrust of these figures is clear: the spread is great, and the outlier cases subject defendants to punitive damages that dwarf the corresponding compensatories. ${ }^{100}$

In Baker, the Court dealt "a decisive blow" to the claim that punitive damages are out of control. ${ }^{101}$ Upon reviewing the empirical scholarship for the first time, the Court silenced much of the noise in the debate over punitive damages. ${ }^{102}$

The leading empirical scholars in this field, Thomas Eisenberg and his coauthors chief among them, have shown that: (1) punitive damages are infrequently awarded, ${ }^{103}$ (2) the amount of punitive damages is highly correlated to the amount of compensatory damages, ${ }^{104}$ (3) the median ratio of punitive to compensatory damages is less than $1.0,{ }^{105}$ and (4) punitive ted).

100. Baker, 554 U.S. at 497-500 (emphasis added) (footnotes omitted) (citations omit-

101. Sharkey, supra note 5, at 38 .

102. Baker, 554 U.S. at 497-98 nn.13-15. Eisenberg et al. have shown that all of the high mean and high variance data referenced in Baker were attributed to compensatory damage awards of less than $\$ 10,000$. Eisenberg et al. 2010, supra note 17, at 16 . The implication is that these awards may have had high ratios, but the awards themselves were not severe (or severe enough) given the low compensatory damages.

103. See Eisenberg et al. 2002, supra note 17, at 745 (noting that punitive damages are "rare"); Eisenberg et al. 1997, supra note 17, at 635 (showing that punitive damages are awarded in less than $10 \%$ of trials in which plaintiffs won); see also Stephen Daniels \& Joanne Martin, Myth and Reality in Punitive Damages, 75 MinN. L. Rev. 1, 31 (1990) (reporting that punitive damages were awarded in $8.8 \%$ of positive plaintiff verdicts); Sebok, supra note 17, at $964 \&$ n. 19 (showing that punitive damages have been awarded in $2 \%$ to $9 \%$ of positive plaintiff verdicts); Vidmar \& Rose, supra note 17, at 487 (reporting that awards were "strikingly low").

104. Eisenberg et al. 2002, supra note 17, at 745; Eisenberg et al. 1997, supra note 17, at 647; see also Sebok, supra note 17 , at 970-71.

105. See Eisenberg et al. 2002, supra note 17, at 754 (reporting that the vast majority of cases clustered around a ratio of 0.88 to 0.98); Eisenberg et al. 2006, supra note 17, at 269 
damages are most likely to be awarded for intentional torts and economic wrongs. ${ }^{106}$ The empirical evidence shows that punitive damages are infrequent, stable, and predictable, ${ }^{107}$ and that the myth of out-of-control punitive damages is "groundless." 108

If the aggregate amount of punitive damages is not the problem, then what is? The Baker Court identified the real problem as the variance of awards, which translates into the "stark unpredictability of punitive awards." 109 Finding no empirical or theoretical support for the proposition that variance is a good thing, the Court disapproved of variability between awards for the same or similar conduct and the resulting unpredictability. ${ }^{110}$

\section{The Problem of Low Frequency, High Severity Awards}

The main thrust of the criticism of punitive damages relates to the predictability of punitive damages at the individual level. ${ }^{111}$ Unpredictability suggests arbitrariness and incoherence in the litigation system. Defendants cannot gauge ex ante the range of liability arising from their conduct. Individual judgments, the argument goes, are incoherent due to a lack of case-by-case predictability. Cass Sunstein, Daniel Kahneman, and David Schkade have prominently advanced this argument. ${ }^{112}$ They argue that while jurors consistently share moral judgments about a defendant's conduct, they have difficulty in mapping such judgments onto an unbounded scale of dollars. ${ }^{113}$ The problem of monetizing shared moral sentiments can lead to erratic, unpredictable, and arbitrary awards. ${ }^{114}$

The problem of uncertainty and unpredictability is a legitimate policy concern. But the statement of the problem must be refined further. First of all, empirical evidence undercuts much of the unpredictability claim. Individual cases are predictable based on statistical inference. If one were to predict in any given case that, first, punitive damages would not be awarded, and second, if punitive damages were awarded at all, the amount awarded

(reporting median ratios of 0.62 and 0.66 in jury and bench trials); Vidmar \& Rose, supra note 17 , at 492 (reporting a median ratio of 0.67 ).

106. Eisenberg et al. 1997, supra note 17, at 633; see also Sebok, supra note 17, at 967.

107. See Sebok, supra note 17, at 962-76 (showing that punitive damages are not "out of control" based on the metrics of frequency, amount, and predictability).

108. Id. at 960 .

109. Exxon Shipping Co. v. Baker, 554 U.S. 471, 472 (2008); see also Pac. Mut. Life Ins. Co. v. Haslip, 499 U.S. 1, 42 (1991) (Kennedy, J., concurring) (noting the problem of "the size and recurring unpredictability of punitive damages awards"); id. at 43 (O'Connor, J., dissenting) (noting the problem of "uncertainty" in the process and "inconsistent and unpredictable results").

110. Baker, 554 U.S. at 499-501 (citing as an example BMW of N. Am., Inc. v. Gore, 517 U.S. 559, 565 n.8 (1996)).

111. See Polinsky, supra note 29 , at 672 .

112. Sunstein, Kahneman \& Schkade, supra note 7.

113. Id. at 2074 .

114. Id. 
would be correlated to the compensatory damages, that prediction would be fairly reasonable as a matter of statistics and probability. Punitive damages are predictable, but obviously predictions are not perfect. Deviations from expectation will occur.

No serious person argues that uncertainty can be eliminated entirely from the litigation system. ${ }^{115}$ We live in an uncertain world, and some of the major achievements in economics have dealt with the study of risk and uncertainty. ${ }^{116}$ Uncertainty and randomness are inherent in the legal system. Nor should there be any entitlement in the civil litigation system to certainty of outcomes. Certainty in litigation is achieved only with fiat rules like the quantitative caps seen in Campbell and Baker. ${ }^{117}$ Otherwise, the legal process is inherently risky as to outcomes on liability and damages. A meritorious case is always subject to uncertainty of outcome. ${ }^{118}$ With perfect bilateral omniscience, all cases would settle under the terms dictated by the predicted winner; with perfect single-party omniscience, virtually all cases would go to trial because the omniscient party would not settle for anything less than the winning outcome net of transaction costs. Most cases settle because uncertainty is the governing condition. Uncertainty is a fact of life, and variance of outcomes is a routine feature of the litigation system. ${ }^{119}$

The real policy issues are what is the role of variance with respect to punitive damages, and what degree of variability is acceptable or good? Here, empirical scholarship does not provide the answer. As Eisenberg comments, "How much variation to allow is a question of judgment and policy." ${ }^{120} \mathrm{~A}$ normative theory of variance in punitive damages is needed.

Outlier judgments are unpredictable. ${ }^{121}$ Outliers have two attributes. First, the awards are low frequency events. Low frequency is defined here as small probabilities of occurrence based on the class of all cases awarding punitive damages. Since punitive damages are awarded infrequently, ${ }^{122}$ a

115. See Theodore Eisenberg, Commentary on "On the Nature of Bankruptcy": Bankruptcy and Bargaining, 75 VA. L. Rev. 205, 210 (1989) ("When both parties agree on the outcome of a dispute there is little reason to litigate."). It has long been recognized that in legal analysis "certainty generally is illusion." Oliver Wendell Holmes, The Path of the Law, 10 HaRv. L. REv. 457, 466 (1897).

116. See Interview with Kenneth Arrow, Professor, Stanford University, in Three Nobel Laureates on the State of Economics, Challenge, Jan.-Feb. 2000, at 13, 19-20.

117. Cf. Sunstein, Kahneman \& Schkade, supra note 7, at 2077, 2126 (arguing that "unpredictable awards create both unfairness and (on reasonable assumptions) inefficiency" but that "both caps and multipliers are extremely crude" devices).

118. See Rhee, Price Theory of Legal Bargaining, supra note 26, at 664 ("It can never be assumed that parties should try to accurately predict the decision of the deliberative body because this assumes a level of predictive power beyond the credible allowance of a rational person.").

119. George L. Priest \& Benjamin Klein, The Selection of Disputes for Litigation, $13 \mathrm{~J}$. Legal Stud. 1, 16-19 (1984).

120. Eisenberg et al. 1997, supra note 17, at 653.

121. See Sunstein, Kahneman \& Schkade, supra note 7, at 2077 (noting the problem of "a risk of extremely high awards").

122. See supra note 103. 
low frequency award is an outlier of the small class of cases (i.e., they are an infrequent occurrence within a set of infrequent events).

Second, outlier awards are low frequency events because they are high severity losses. High severity is defined here as the high dollar value of an award of punitive damages relative to the defendant firm's wealth. Similar to the concept of the marginal utility of money, the same amount of money has different effects depending on a corporate defendant's wealth. High dollar values in absolute terms are not necessarily a high severity award. The $\$ 2$ million award in Gore is not a large number for a national firm like BMW, but it could be a devastating sum for a smaller firm. Another example: if compensatory damages are $\$ 20$ billion, say hypothetically for harms related to British Petroleum's oil spill in the Gulf of Mexico, would a \$20 billion award of punitive damages be so shocking? Likewise, a high multiple does not necessarily lead to a high severity award. Suppose the compensatory damage award is minimal, say $\$ 100$, and punitive damages are awarded at a $90 x$ multiple $(\$ 9,000)$. Would such a case have merited the attention of the Supreme Court? Thus, neither a high multiple nor a large absolute value of punitive damages nor both is necessarily problematic.

The rare cases yield a low frequency, high severity award, and thus they are unpredictable. A high severity award exceeds the boundary of ordinary expectation because it imposes financial distress on firms. ${ }^{123}$ Financial distress, such as insolvency, substantially disrupts a firm's ordinary operations. It has significant economic consequences and imposes significant economic costs, including the liability amount and the costs associated with disruptions to the firm's operations, transaction costs associated with recapitalization, and insolvency. Moreover, actual awards are not the only economic detriment. The risk of being subject to a low frequency, high severity award has implications on settlement. Implied, but not stated, in Baker is that outlier judgments may coerce settlements, force overpayment, and thus overdeter defendants. ${ }^{124}$

A summary of the essential problem is helpful. The supposed problem of unpredictability is too general a proposition. Unpredictability is tied to the problem of variance. While most awards of punitive damages are predictable within a range of expectation, a small class of awards is highly unpredictable and economically harmful because the awards exceed the range of ordinary expectation as to frequency and severity. Problematic awards occur infrequently. Infrequent events are harmful because they pose severe economic consequences. When an award meets these conditions, it is defined as a low frequency, high severity award. Such extraordinary awards can be like a lightning strike, infrequent as to occurrence and severe as to outcome. ${ }^{125}$ The

123. See Viscusi, supra note 17 , at 285 ("The high stakes and high variability of punitive damage awards are of substantial concern to companies, as punitive damages may pose a catastrophic threat of corporate insolvency.").

124. Sharkey, supra note 5, at 26.

125. See Koenig, supra note 29, at 174 ("Plaintiffs are depicted as filing needless suits for the chance of winning a 'lightning strike' punitive damages payout."). 
risk associated with these cases affects the whole of the tort and dispute resolution systems.

\section{LAW AND ECONOMICS THEORY AND CRITIQUe}

\section{A. Standard Law and Economics Theory}

The standard law and economics theory of punitive damages advances deterrence as the normative goal. The law should optimally deter defendants by causing them to internalize the full cost of all wrongful conduct. ${ }^{126}$ This basic idea originates from Judge Learned Hand's famous exposition of the negligence standard in United States v. Carroll Towing Co. ${ }^{127}$ The economic theory of punitive damages is based on the idea of minimizing social cost through optimal deterrence. ${ }^{128}$

The leading proponents of this theory are Mitchell Polinsky and Steven Shavell. They argue that punitive damages should only be awarded if a defendant has a chance to escape liability for the harm it causes. ${ }^{129}$ When the tort system operates perfectly in imposing liability for all wrongful conduct, there is no reason for punitive damages since defendants fully internalize the cost of wrongful conduct. Only when a defendant can escape liability should punitive damages be awarded in an amount equal to the escaped liability as a means of preventing the underdeterrence of wrongful conduct. From this perspective, when a defendant has a chance of escaping liability for wrongful conduct, the total damages should be the harm caused multiplied by the reciprocal of the probability of being found liable. ${ }^{130}$ This concept can be expressed in a mathematical formula: $D=H \times \frac{1}{P}$ where $D$ is the total damages award, $H$ is the magnitude of the harm, and $P$ is the probability of being found liable. ${ }^{131}$ The key point here is that a defendant should pay a liability amount in excess of the compensatory damages equal to the amount of the harm the defendant caused for which he would not otherwise pay. ${ }^{132}$ 74

126. Calandrillo, supra note 17 , at $779-80$; Polinsky \& Shavell, supra note 17 , at $873-$

127. 159 F.2d 169, 173 (2d Cir. 1947)

128. See Polinsky \& Shavell, supra note 17, at 883 n.31 (extending the Hand Formula analysis to a theory of punitive damages); see also Sebok, supra note 17, at 977 ("Polinsky and Shavell, who have put forward the purest and most straightforward account of punitive damages and efficient deterrence, view punitive damages as an extension of the Hand Test used in negligence.”).

129. Polinsky \& Shavell, supra note 17 , at 874.

130. Id.; see also Calandrillo, supra note 17 , at 780.

131. Polinsky \& Shavell, supra note 17, at 889 n.48. Since total damage $D$ equals compensatory damage for the harm $H$ plus punitive damages $E$, punitive damages can be stated as: $E=H\left(\frac{1}{P}-1\right)$ where the term $\left(\frac{1}{P}-1\right)$ is the punitive damages multiplier. Id. at $890 \mathrm{n} .51$.

132. Polinsky and Shavell do not expect the multiplier to yield high multiples in most cases. Id. at 891-92. To reduce the evidentiary and decisionmaking burdens, they recommend 
The standard law and economics theory is seen at work in Mathias $v$. Accor Economy Lodging, Inc. ${ }^{133}$ There, the plaintiffs suffered bedbug bites while staying at the defendant's motel. The jury awarded each plaintiff $\$ 5,000$ in compensatory damages and $\$ 186,000$ in punitive damages, a multiple of 37.2x. ${ }^{134}$ Judge Posner rejected the defendant's argument that the punitive damages violated Gore and Campbell:

The hotel's attempt to pass off the bedbugs as ticks, which some guests might ignorantly have thought less unhealthful, may have postponed the instituting of litigation to rectify the hotel's misconduct. The award of punitive damages in this case thus serves the additional purpose of limiting the defendant's ability to profit from its fraud by escaping detection and (private) prosecution. If a tortfeasor is "caught" only half the time he commits torts, then when he is caught he should be punished twice as heavily in order to make up for the times he gets away. ${ }^{135}$

The court affirmed the award of punitive damages on the basis that the defendant had escaped liability in many other transactions with motel customers, which justified an upward deviation from Campbell. Thus, Mathias adopts the standard law and economics reasoning that escaped culpable conduct must be "recaptured" through the imposition of punitive damages such that the cost of a defendant's activity is fully internalized.

\section{B. Critique of the Standard Theory}

Despite the mathematical elegance of the standard law and economics theory, the model is incomplete from the standpoint of how punitive damages should work. Escaped liability is an important factor to consider from a deterrence perspective. It is well known that many legitimate claims go undiscovered or are not pursued for various reasons, ${ }^{136}$ and thus defendants "internalize far less than the full cost of the losses they inflict." ${ }^{137}$ But the

providing a jury with probabilities in increments of one-tenths. $I d$. at 892 . Thus, the low end of the probability of being found liable ( 0.1 or 10 percent) yields a multiple of 9x compensatory damages-which coincidentally is the upper limit of the cap in Campbell.

133. 347 F.3d 672 (7th Cir. 2003) (Posner, J.).

134. Mathias, 347 F.3d at 674.

135. Id. at 677.

136. See Tom Baker, The Medical Malpractice Myth 68-69 (2005); Deborah R. Hensler et al., RAND Inst. For Civil Justice, Compensation for Accidental Injuries In the United States 142 (1991); Marc A. Franklin et al., Accidents, Money, and the Law: A Study of the Economics of Personal Injury Litigation, 61 Colum. L. Rev. 1, 10 (1961); John C.P. Goldberg, Twentieth-Century Tort Theory, 91 Geo. L.J. 513, 554 (2003); Michael J. Saks, Do We Really Know Anything About the Behavior of the Tort Litigation System-And Why Not?, 140 U. PA. L. Rev. 1147, 1183 (1992).

137. Saks, supra note 136, at 1283 n.533; see also Keith N. Hylton, Litigation Costs and the Economic Theory of Tort Law, 46 U. Miami L. Rev. 111, 113-14 (1991). Corporate defendants also do not fully internalize the cost of torts due to the rule of limited liability, which is a subsidy to corporations. See Henry Hansmann \& Reinier Kraakman, Toward Unlimited Shareholder Liability for Corporate Torts, 100 YALE L.J. 1879, 1916-23 (1991); David W. 
standard law and economics model fails to account for other important variables in the tort and litigation systems.

In the empirical world, litigation involves risk, and the parties are the risk bearers. Kip Viscusi provides the following critique of law and economics analysis:

The standard economic theory of punitive damages and incentives casts the analysis within a highly stylized situation of certainty. Does the economic value of the definite harm resulting from an action exceed the benefits? The task then becomes setting a damage amount so that the company recognizes the full costs of its actions and exercises an appropriate degree of care in its activities. These formulations are overly simplistic, however, because they neglect potential risks that affect corporate actions and the linkage of the company's behavior to the societal effects.... To understand fully what legal sanctions may be appropriate when corporate decisions generate social harms, it is necessary to explicitly account for the tradeoffs inherent in corporate risk decisionmaking. ${ }^{138}$

Like the Hand Formula, the standard law and economics model of punitive damages is built on the edifice of probability and expected value. But the model fails to account for the role of risk in the decisionmaking of parties.

Probability and variance are entirely different concepts. ${ }^{139}$ To illustrate, assume two coin flips: in coin flip $A$, one gets $\$ 20$ if the coin is heads and $\$ 0$ if it is tails; in coin flip $B$, one gets $\$ 40$ if the coin is heads and one must pay $\$ 20$ if it is tails. For both coin flips $A$ and $B$, the expected value based on the probabilities is $\$ 10$. However, it is obvious that the variances of the two coin flips are different. In coin flip $A$, the outcomes are $[\$ 20, \$ 0]$ for a spread of $\$ 20$, and in coin flip $B$, the outcomes are [\$40,\$20] for a spread of $\$ 60$. The greater the spread of potential outcomes, the greater the risk. Here, coin flip $B$ has more variance, and is thus more risky. A theory of punitive damages must account for the quality of riskiness of punitive damages.

Another empirical fact is that the litigation system is not composed of homogenous parties. Heterogeneous parties act under a veil of uncertainty and react differently to both similar and dissimilar circumstances. The most important difference among parties is that defendants who are exposed to the largest punitive damage awards are typically corporations, whereas most plaintiffs are individuals. Corporate defendants and individual plaintiffs view and manage risks differently. The former are repeat players in the litigation system. The outcomes of individual lawsuits do not affect the

Leebron, Limited Liability, Tort Victims, and Creditors, 91 Colum. L. Rev. 1565 (1991); Robert J. Rhee, Bonding Limited Liability, 51 WM. \& MAry L. Rev. 1417, 1433-35 (2010).

138. Viscusi, supra note 17, at 299 (footnote omitted). "The implicit message of the economic model is that we do not need to be concerned about the high proportion of cases that are settled because the outcomes of settled cases approximate the positions the parties would have occupied after a trial on the merits." Janet Cooper Alexander, Do the Merits Matter? A Study of Settlements in Securities Class Actions, 43 Stan. L. Rev. 497, 502 (1991).

139. The Princeton Companion to Mathematics 265 (Timothy Gowers ed., 2008). 
portfolio of corporations for the most part. On the other hand, the outcome of the lawsuit for an individual plaintiff is significant. By virtue of different circumstances, the degrees of variance experienced by the different classes of plaintiffs and defendants are different. Yet the standard law and economics model of punitive damages does not account for this difference. ${ }^{140}$

If most defendants are corporations, punitive damages and the threat of outlier verdicts must affect corporate finance and risk management, and these factors may affect litigation behavior. Punitive damages can threaten the solvency of firms, require firms to recapitalize lost capital, and otherwise affect the firm's operations just as any large liability or incurred business cost can. These financial effects must be modeled into an economic theory of punitive damages.

Lastly, in the litigation system, most cases settle. ${ }^{141}$ Dispute resolution scholars claim that settlement occurs "in the shadow of the law." ${ }^{142}$ Settlement is the large unseen part of the tort system because most disputes are privately ordered. ${ }^{143}$ Settlement is irrelevant to the efficiency aspiration of the law only if the aggregate outcomes in settlement reflect the probabilistic value of trial outcomes. ${ }^{144}$ Settlements may distort the efficiency aspiration of tort law, thus undermining efficiency and imposing social cost. ${ }^{145}$ Tort theory exists in the shadow of settlement, and "[i]ts efficiency aspiration can be achieved only within a system that settles most disputes." 146 Many scholars have recognized the issue-what is the effect of settlement prac-

140. Polinsky and Shavell's model assumes risk-neutral parties and diversified shareholders. Polinsky \& Shavell, supra note 17, at 886-87.

141. See Alexander, supra note 138, at 525 (noting the settlement rate is likely $60 \%-70 \%$ ); Gillian K. Hadfield, Where Have All the Trials Gone? Settlements, Nontrial Adjudications, and Statistical Artifacts in the Changing Disposition of Federal Civil Cases, 1 J. EMPIRICAL Legal Stud. 705, 730 tbl.7 (noting that $68.7 \%$ of federal civil cases in 2000 were settled); see also Marc Galanter, The Vanishing Trial: An Examination of Trials and Related Matters in Federal and State Courts, 1 J. Empirical Legal Stud. 459, 462-63 tbl.1 (2004) (noting the civil trial rate in federal court in 2002 to be $1.8 \%$ ); Saks, supra note 136, at 1212-13 (noting trial rate of less than $10 \%$ ).

142. Robert H. Mnookin \& Lewis Kornhauser, Bargaining in the Shadow of the Law: The Case of Divorce, 88 YAle L.J. 950 (1979).

143. See Lawrence M. Friedman, A History of American law 357, 363 (3d ed. 2005) (explaining that the study of appellate cases can be quite misleading because it is "the tip of a huge iceberg of cases"); Koenig, supra note 29, at 172; Rhee, supra note 35, at 127; Saks, supra note 136, at 1212 ("The focus on trials is somewhat misplaced, because the great majority of cases are settled, not tried.").

144. Alexander, supra note 138, at 499; Rhee, supra note 35, at 136-37; see also Richard A. Posner, A Theory of Negligence, 1 J. LEGAL STUD. 29 (1972) (arguing that common law courts set the efficient level of liability through the cost-benefit analysis embedded in the Hand Formula).

145. Bruce L. Hay \& Kathryn E. Spier, Settlement of Litigation, in 3 The New PaLgrave Dictionary of Economics and the Law: 442, 447 (Peter Newman ed., 1998); Rhee, supra note 35, at 129; Kathryn E. Spier, A Note on the Divergence Between the Private and Social Motive to Settle Under a Negligence Rule, 26 J. Legal Stud. 613, 614-16 (1997); see also Alexander, supra note 138, at 501-23.

146. Rhee, supra note 35 , at 127 
tices on punitive damages, and vice versa? ${ }^{147}$ Yet the standard law and economics model does not account for any potential difference between settlement and trial, and the potential effects of punitive damages on either settlement rates or amounts.

In summary, variance is an important empirical fact of the litigation system. Even a normative model cannot disengage from reality and must account for how the litigation system really works and parties really behave. An economic theory of punitive damages should incorporate the realities of risk, risk management, and corporate finance into a model of how punitive damages actually work and how they should work.

\section{Toward a Complete Theory of Optimal Liability}

Optimal deterrence is achieved through nothing less than full cost internalization. ${ }^{148}$ The standard law and economics model concerns escaped liability, but it does not consider other more important factors in the pricing of legal disputes in the settlement process. The threat of punitive damages plays an important role in regulating the value of tort actions, and it can produce inefficiencies through over- or underdeterrence.

Punitive damages may impose too much legal liability or economic cost on defendants arising from the litigation. In addition to the cash value of legal liability, the threat and the uncertainty of punitive damages create financial costs that function very much like economic penalties for wrongful conduct. Firms can go insolvent. Their cost of equity can increase, resulting in reduced stock value. If a firm must be recapitalized after a large judgment, it could bear the large transaction costs of raising capital. Factoring in information about the adverse litigation outcome, the new capital may cost more. Collectively, these economic costs must be factored into the calculus of cost internalization and deterrence.

With respect to the cost of legal liability, the method of calculating the amount of "cost" imposed on the tortfeasor must be explored. The cost of liability must be conceptualized in two ways because it is calculated under two different methods: the parties calculate cost in private settlement, and the court calculates it in public adjudication. If these valuational methods produce approximately the same results, there would be no issue. However, scholars have recognized that settlement practices may create social costs and undermine optimal deterrence when valuations diverge. ${ }^{149}$ For reasons explained in the next Part, the private cost calculations in settlement diverge from the public calculations of courts. The idea of efficient deterrence is implicitly based on the judicial standard of measuring cost; after all, courts determine the legal standards under which cases are decided. If so, we must explore how the possibility of punitive damages affects settlement values, and whether these values are consistent with the expected value of judicial

147. See supra note 29 .

148. Polinsky \& Shavell, supra note 17, at 873; Sharkey, supra note 17, at 365.

149. See infra Section III.B. 
outcomes. In other words, does the threat of punitive damages increase or decrease settlement value from the reference point of risk neutrality and expected value of trial outcomes?

An economic theory of punitive damages should advance the policy goal of full cost internalization. Achieving this objective requires implementing several instrumental goals: (1) mitigating escaped liability and deterring recidivism, (2) factoring the financial and economic costs of punitive damages on defendants, and (3) accounting for deviations from judicial valuations in settlement practices. The standard law and economics theory is already well developed with respect to the problem of escaped liability and recidivism. Economic theory must now account for the more important factors affecting litigation behavior and valuation. The Supreme Court in Baker suggested that punitive damages cast a "shadow" on settlement ${ }^{150}$ but found variance to be a bad thing. ${ }^{151}$ Parts III and IV analyze these unresolved aspects of punitive damages. They present a financial economic analysis of variance and punitive damages, and its relationship to settlement.

\section{Risk Arbitrage in Settlements}

\section{A. Corporations as Defendants}

An inquiry into the relationship between punitive damages and settlement requires that we first consider the heterogeneous risk profiles of the litigating parties. The economic interests of corporations are at the center of the debate on punitive damages. Businesses constitute an overwhelming proportion of defendants in tort actions. ${ }^{152}$ The punitive damages debate concerns the wealth and well-being of corporations and raises larger economic issues. ${ }^{153}$ Corporations are vital to the national economy, and they

150. Exxon Shipping Co. v. Baker, 554 U.S. 471, 498 n.15 (2008).

151. Id. at 500-01; see also Koenig, supra note 29, at 208-09 (arguing that almost no systematic knowledge exists as to the effect of punitive damages on settlement).

152. It has long been recognized that a principal concern of the field of torts is business interests. See Holmes, supra note 115, at 467 ("But the torts with which our courts are kept busy to-day are mainly the incidents of certain well known businesses."). Even in the modern era, a majority of tort cases involve organizational or institutional defendants. Samuel R. Gross \& Kent D. Syverud, Don't Try: Civil Jury Verdicts in a System Geared to Settlement, 44 UCLA L. REv. 1, 19-20 (1996) (noting that most nonvehicular tort cases were against large businesses or governments); see also Gillian K. Hadfield, Exploring Economic and Democratic Theories of Civil Litigation: Differences Between Individual and Organizational Litigants in the Disposition of Federal Civil Cases, 57 Stan. L. Rev. 1275, 1298 (2005) (noting that in 2000 "fully $60 \%$ of federal civil cases involved an individual suing an organizational defendant").

153. See Polinsky \& Shavell, supra note 17, at 948-52 (discussing the effect of punitive damages on corporate defendants); Sharkey, supra note 5, at 36 (noting that corporate and business interests have led the attack on punitive damages); Viscusi, supra note 17, at 285 (arguing that punitive damages pose a threat of corporate insolvency). 
represent large aggregations of the nation's wealth. ${ }^{154}$ The Court has explicitly recognized the importance of corporate economic interests. ${ }^{155}$ Frank Easterbrook has famously asserted that " $[\mathrm{t}] \mathrm{he}$ Supreme Court is a regulator." 156 Judge Easterbrook's assertion rings true in the area of punitive damages, which itself has a large impact on corporate enterprises. ${ }^{157}$ There can be no doubt that the larger policy concerns regarding corporate wealth, redistribution, and economic regulation underlie the constitutional debate.

Several law and economics scholars have suggested that punitive damages do not deter corporations. ${ }^{158}$ Polinsky and Shavell have argued that "the imposition of punitive damages on firms may not lead to the punishment of blameworthy individuals within them; thus, the goal of punishing blameworthy employees may not be well promoted by imposing punitive damages on firms." ${ }^{159}$ This argument is consistent with the law and economics theory that the firm is nothing more than a nexus of contracts ${ }^{160}$ and the viewpoint that diminishes the existence of the firm as an entity of independent significance. ${ }^{161}$ So the argument seems to go, since the corporation is "just a relatively stable corner of the market in which autonomous property owners freely contract," 162 deterrence is more effective when it imposes targeted liability on the culpable autonomous person within that nexus of contracts rather than on the firm which has been anthropomorphized to bear independent social responsibility for its harmful actions.

This argument, however, is unpersuasive. Corporations as firms are deterred by stiff penalties. We saw the deterrence effect in action in Gore. The undisclosed repairs were done pursuant to company policy, but immediately after the jury's verdict of $\$ 4$ million in punitive damages the company

154. See generally, Adolf A. Berle \& Gardiner C. Means, The Modern Corporation AND Private Property (1991).

155. See supra Section I.A.

156. Frank H. Easterbrook, The Supreme Court, 1983 Term-Foreword: The Court and the Economic System, 98 HARv. L. Rev. 4, 4 (1984).

157. See Jeffrey Rosen, Keynote Address, Santa Clara Law Review Symposium: Big Business and the Roberts Court, 49 SANTA Clara L. Rev. 929, 933-35 (2009) (arguing that the Supreme Court has favored business and corporate interests); Jeffrey Rosen, Supreme Court Inc., N.Y. Times, Mar. 16, 2008, at MM38 (same); see also Epstein, Landes \& Posner, supra note 95, at 2 (noting statistically significant pro-business trend in the Roberts Court from 2005 to 2009).

158. E.g., Polinsky \& Shavell, supra note 17; see, e.g., Viscusi, supra note 17.

159. Polinsky \& Shavell, supra note 17, at 949.

160. Frank H. Easterbrook \& Daniel R. Fischel, The Economic Structure of Corporate LaW 12 (1991). This idea in the legal academy traces its pedigree to R.H. Coase, The Nature of the Firm, 4 Economica 386 (1937). See also Michael C. Jensen \& William H. Meckling, Theory of the Firm: Managerial Behavior, Agency Costs and Ownership Structure, 3 J. Fin. Econ. 305, 311 (1976) (arguing that the firm "is simply one form of legal fiction which serves as a nexus for contracting relationships").

161. William T. Allen, Our Schizophrenic Conception of the Business Corporation, 14 Cardozo L. Rev. 261, 265 (1992).

162. Id. 
changed its policy to make full disclosure. ${ }^{163}$ Firms respond to costs and risks, and perhaps do so more rationally than individual persons. The group of autonomous individuals is collectively deterred by punitive damages, and the deterrence is more effective because collective liability produces a set of consensus decisions as to the corporation's future activities and necessary monitoring within the firm. Moreover, the question of fairness-whether innocent shareholders and customers should be made to pay punitive damages-is irrelevant in an economic analysis of the firm. The corporate form bundles and packages the risks of the firm's activities, and legal liability is simply one component of the larger business risk. ${ }^{164}$ Corporations exist in a tort system that imposes vicarious liability on firms. ${ }^{165}$

However, the corporation as a tort defendant raises real economic issues. First, there is the issue of social wealth redistribution from the corporate enterprise to plaintiffs. ${ }^{166}$ Second, corporations are repeat players in the tort market whereas plaintiffs are single-shot players, ${ }^{167}$ and this difference is important in modeling the dynamics of settlement. Third, corporations as defendants also implicate corporate finance and risk management issues. A theory of how punitive damages should work must take into account these empirical facts.

A financial economic analysis requires a careful assessment of the risk posed by punitive damages and how heterogeneous parties standing in different circumstances price that risk into the value of the litigation as part of the settlement process. In this respect, risk is categorized into two broad categories: ordinary and catastrophic.

\section{B. Risk Arbitrage in Ordinary Cases}

In most cases, punitive damages are an ordinary cost of doing business. Liability is modeled and monitored, costs are budgeted, and risks are managed through retention, insurance, and mitigation. Ordinary risk is the risk of a loss within the normal, expected range of losses, and such loss does not financially distress a firm or create significant problems for corporate financing. This risk can encompass large sums and high multiples since a corporation can face large judgments on a routine basis.

When liability is ordinary, the corporate defendant will usually have a risk arbitrage opportunity. In most ordinary cases, corporate defendants demand and receive a risk premium from the plaintiff. This is a bad thing

163. BMW of N. Am., Inc. v. Gore, 517 U.S. 559, 563, 566 (1996).

164. "The reason for holding shareholders liable is simple: they have purchased the right to residual return." Rhee, supra note 137, at 1424.

165. See Pac. Mut. Life Ins. Co. v. Haslip, 499 U.S. 1, 14-15 (1991) (holding that firms can be held vicariously liable for punitive damages under the doctrine of respondeat superior).

166. See Del Rossi \& Viscusi, supra note 17, at 124-25 (noting 100 punitive damage awards of $\$ 100$ million or more from 1985 to 2008 , totaling $\$ 124.78$ billion).

167. See Marc Galanter, Why the "Haves" Come Out Ahead: Speculations on the Limits of Legal Change, 9 L. \& Soc’y Rev. 95, 97 (1974). 
because it systematically reduces settlement value from the benchmark of the expected trial outcome. This arbitrage is made possible for three reasons: (1) risk aversion, (2) repeat play and portfolio variance, and (3) opportunity cost.

Risk aversion. Most natural persons are risk averse. ${ }^{168}$ They will pay money to eliminate or transfer risk to a willing risk bearer, which is the raison d'être of the insurance industry. ${ }^{169}$ The academic discipline of financial economics and the modern capital markets is based on the fundamental assumption that investors are risk averse and thus must be paid to bear economic risk for loaning capital. ${ }^{170}$ Risk aversion among most people is a plain fact of the dispute resolution system.

In contrast, corporations are generally considered risk neutral. Although they may sometimes behave as if they were risk averse, ${ }^{171}$ they generally strive to operate in a risk-neutral fashion. ${ }^{172}$ Risk-neutral decisions maximize expected return whereas risk-averse decisions sacrifice expected return for certain outcomes. ${ }^{173}$ If a shareholder maintains a diversified portfolio of stocks, she benefits from risk-neutral decisions even when some stocks in the portfolio suffer significant losses due to risky decisions.

This difference in risk preference has an important implication: riskaverse plaintiffs will accept a sum certain that is less than the expected value of variable outcomes. Settlement represents a sum certain whereas trial represents liability or no-liability outcomes. A simple example illustrates the point. If trial represents an equal probability of liability and no liability with a spread of $[100,0]$, a risk-averse plaintiff may accept a discounted settlement of 40 rather than the expected value of 50 for the benefit of eliminating the risk of trial. ${ }^{174}$ Viewing the probabilities and risks similarly, a riskneutral defendant will pay up to 50, but if it knows that the plaintiff is risk

168 See Price v. Marshall Erdman \& Assocs., Inc., 966 F.2d 320, 327 (7th Cir. 1992) (Posner, J.); Rhee, supra note 78, at 89.

169 Because insurers have expenses and require a profit, premiums include the actuarial value of losses plus operating expenses and profits. This "loading charge" is in the range of $10 \%-50 \%$ of the premium. Scott E. Harrington \& Gregory R. Niehaus, Risk ManageMENT AND INSURANCE 170 ( $2 \mathrm{~d}$ ed. 2004).

170 See Markowitz, supra note 34.

171 Corporations can sometimes behave like risk-averse persons. Rhee, supra note 35 , at 153. Risk aversion may manifest through the decisions of risk-averse managers. Id. at 152; Koenig, supra note 29, at 170 . Corporations buy insurance like a risk-averse entity, but they do so because insurance may provide real financial and economic advantages that exceed the negative value of fairly priced insurance premiums. See HARRINGTON \& NIEHAUs, supra note 169, at 171-74; Victor P. Goldberg, The Devil Made Me Do It: The Corporate Purchase of Insurance, 5 Rev. L. \& Econ. 541 (2009); J.B. Heaton, Settlement Pressure, 25 InT'L Rev. L. \& ECon. 264, 272-73 (2005); David Mayers \& Clifford W. Smith, Jr., On the Corporate Demand for Insurance, $55 \mathrm{~J}$. Bus. 281 (1982).

172 Rhee, supra note 35 , at $152-53$.

173. See Joy v. North, 692 F.2d 880, 886 (2d Cir. 1982); Stephen M. Bainbridge, CORPORATION LAW AND ECONOMICS 259-63 (2002).

174 The same concept explains why a policyholder will pay an insurance premium of 100 when the expected actuarial loss is 75. See supra note 169. 
averse and is thus willing to take less than the expected value, a settlement will be had in the range of 40 to 50 . All else being equal, the risk-averse party fares worse in settlement than the risk-neutral party because the former will concede additional value from the expected value to eliminate the risk of an all-or-nothing variable trial outcome. Since the plaintiff in a tort action is typically more risk averse, there is a systematic discounting of settlement values in favor of the corporate defendant.

Repeat play and portfolio variance. A corporate defendant is able to mitigate its risk exposure by holding a basket of lawsuits. Companies like State Farm or BMW are repeat players while plaintiffs like Campbell and Gore are single-play parties. This difference is important. A single-play party is exposed to the all-or-nothing aspect of a trial, in itself a risky proposition. A repeat player does not assume this risk but instead bears the risk of the portfolio. If a party has 10 suits with equal probability outcomes of 100 or 0 , the variance of this portfolio would be significantly lower than the variance of a single-shot lawsuit for 100 or 0 . A corporate defendant holding a portfolio of similarly situated cases is exposed to lower risk. In any specific case, it is not subject to the same type of all-or-nothing variance. An important caveat is that no single case can substantially affect the defendant's risk exposure. Barring a catastrophic outlier that can create significant deviations from the expected portfolio return, a repeat-play corpocorporate defendant is exposed to lower risk than is a single-play plaintiff.

Opportunity cost and cost of capital. Plaintiffs and defendants also have different opportunity costs that yield different settlement values. For a corporation, the opportunity cost is the firm's cost of capital, which is the average return expected by the firm's capital providers. Based on the capital asset pricing model, a shareholder with a diversified portfolio earns the market return, which is approximately 11 percent. ${ }^{175}$ It is beyond the scope of this Article to delve into the precise workings of a firm's cost of capital, but suffice it to say that, depending on the riskiness of the firm's cash flow, the cost of capital will fluctuate around this benchmark market return.

A plaintiff's opportunity cost cannot be calculated with the theoretical precision we see in the financial markets. Intuitively, however, the opportunity cost for a tort victim seems higher for different types of tort claims. ${ }^{176}$ If the claim is for a substantial personal injury, the opportunity cost of forgoing settlement may be significant enough to accept an otherwise unfavorable valuation. If the tort claim is based on economic wrongs, like the claims in Browing-Ferris, Haslip, TXO, Campbell and Gore, the opportunity cost of pursuing economic opportunities in business may be higher when compared to the alternative of pursuing a legal action with an uncertain outcome, a lengthy duration to resolution, and high transaction costs.

175. Richard A. Brealey et al., Principles of Corporate Finance 444 (concise 2d ed. 2011).

176. Cf. O'Shea v. Riverway Towing Co., 677 F.2d 1194, 1199 (7th Cir. 1982) (Posner, J.) (noting a tort plaintiff's opportunity cost with respect to compensation and lost earnings). 
Transaction cost in the tort system plays a significant role. The American rule of attorneys' fees, under which parties bear their own attorney fees, is the rule in tort cases. Contingent fees finance litigation, but considerations of opportunity cost and the marginal utility of money weigh unfavorably on individual plaintiffs going up against corporate defendants. Corporate defendants have significantly more resources that they can deploy in litigation, which positively affects the action's outcome. ${ }^{177}$

In summary, when the outcomes are expected and ordinary, risk arbitrage arises from these effects: (1) plaintiffs are more risk averse, (2) single-play plaintiffs bear greater risk arising from the trial outcome, and (3) individual plaintiffs face higher opportunity costs than corporate defendants. The corporate defendant enjoys a risk arbitrage opportunity, which systematically lowers private settlement values as compared to valuations achieved in public adjudications. This difference in values represents a risk arbitrage opportunity.

Optimal deterrence is judicially set by courts in public adjudication, but it is undermined by settlement. Courts and juries are not risk averse because the outcomes do not affect them personally. They are not personally exposed to the outcomes in the case, and thus the variance from single-play and repeatplay scenarios are irrelevant to their decisionmaking. The standard law and economics model states that optimal deterrence is undermined when recidivist tortfeasors escape liability. When the economics of settlement is considered, however, the defendant may partially avoid the amount of liability that a court would set through risk arbitrage, even when his wrongdoing has been discovered and an action is prosecuted. Since most legal disputes settle, the problem of risk arbitrage is great. In cases of ordinary liability, the law of punitive damages should seek to mitigate a corporate defendant's risk arbitrage.

\section{Risk Arbitrage in Catastrophic Cases}

I now consider the effect of catastrophic liability on litigation value. With ordinary losses, standard risk management methods and corporate financing can manage losses even if they are large as to amount or multiple of compensatory damages. However, catastrophic losses pose special challenges, including the problem of insuring or self-insuring, the financial implications of bankruptcy and capital raising, and the settlement pressure associated with a litigation involving a potentially catastrophic loss. When a defendant is confronted with the threat of catastrophic liability, the risk arbitrage opportunity flips in favor of the plaintiff.

Catastrophic losses occur when a judgment is a low frequency, high severity event, meaning that the judgment is an unexpected outlier and a high severity award relative to the firm's wealth. Such losses can lead to financial distress, defined here as substantial disruptions in the firm's ordinary operations resulting from a severe financial loss. Financial distress can result in 
recapitalization of lost capital, increased cost of capital, triggering of insolvency, and filing for bankruptcy.

The fear of unexpected high severity awards, though such awards are highly unlikely, can affect corporate decisionmaking at settlement. One commentator notes the complaints of tort reformers and business interest lobbyists:

Punitive damages claims are viewed as exerting unfair bargaining power against corporate defendants. A Washington lobbyist for a coalition of business and manufacturing groups, states that: "[t]he biggest problem we have with punitive damage claims is that they are used as a lever for out-of-court settlements." The argument of tort reformers is that our civil litigation crisis is due in part to marginal cases that would never be brought without the possibility of punitive damages. ${ }^{178}$

These arguments may be self-serving, but they are not without merit. The basic idea is that plaintiffs can use the risk of a severe punitive damages award, however unlikely that award is, to extract a risk premium in settlement, and thus settlement values deviate upwards from expected judicial outcomes.

If corporations are risk neutral, why would they pay a risk premium in excess of the probabilistic value of the expected punitive damages award? An insurance and risk transfer analysis provides one way to think about the economic cost of catastrophic risk. The measure of financial cost borne by a firm subject to punitive liability can be indirectly inferred from the pricing of catastrophic risk transfer in the insurance market. In other words, if a risk transfer mechanism were available, such as third-party insurance for catastrophic punitive damages, how would this risk transfer be priced?

There is no general insurance solution to the problem of punitive damages. Most courts hold that public policy proscribes insurance coverage for punitive damages liability arising from an intentional tort. ${ }^{179}$ Courts are split on the question of whether punitive damage liability is insurable for reckless, wanton, or grossly negligent conduct. ${ }^{180}$ Absent insurance or an alternative method to transfer the risk of punitive damages, a defendant must retain the risk. ${ }^{181}$ Risk retention is the default method of financing

178. Koenig, supra note 29, at 173-74 (alteration in original) (footnotes omitted).

179. Robert H. Jerry, II \& Douglas R. Richmond, Understanding Insurance Law 547-48 (4th ed. 2007); Robert E. Keeton \& Alan I. Widiss, Insurance LaW 495 (student ed. 1988); see, e.g., Pins v. State Farm Fire \& Cas. Co., 476 F.3d 581 (8th Cir. 2007). The basic rationale is that "a person should not be permitted to insure against harms he may intentionally" inflict or to profit there from. Home Ins. Co. v. Neilsen, 332 N.E.2d 240, 244 (Ind. Ct. App. 1975). But see Tom Baker, Reconsidering Insurance for Punitive Damages, 1998 WIs. L. REv. 101, 101-02 (arguing for the insurability of punitive damages).

180. JERRY \& RichMOND, supra note 179, at 550. Compare Shelton Mut. Ins. Co. v. Dale, 914 So. 2d 698 (Miss. 2005) (recognizing insurability of punitive damages), with Rosenbloom v. Flygare, 501 N.W.2d 597 (Minn. 1993) (declining to permit insuring of punitive damages).

181. "There are four broad methods to finance loss: (1) retention, (2) insurance, (3) hedging, and (4) other contractual risk transfer." HaRRINGTON \& NiEHAUs, supra note 169, at 
loss. Another way to manage the risk is self-insurance, which is a formal financial plan established by the risk bearer to fund losses. ${ }^{182}$ Self-insurance can be funded internally from the firm's cash flow or assets, or externally through borrowing or the sale of stock. ${ }^{183}$ For corporate defendants, risk retention or a more formal self-insurance program can cover large punitive damages as long as they are not severe amounts.

When financial loss is potentially catastrophic, it begets a problem of economic feasibility risk transfer or retention. ${ }^{184}$ Insurance economists have shown that catastrophic risks pose higher capital costs than ordinary risks. ${ }^{185}$ Insurance premium is determined as $P=E(S)+K+R$ where $E(S)$ is the expected value of the claim, $K$ is the operating expenses, and " $R$ is a risk premium which allows for coverage of unforeseen deviations in the claims amount to be paid." 186 The basic problem is that the risk premium $R$ becomes very high when the potential loss is catastrophic. To mitigate the risk of insolvency, an insurer must hold capital sufficient to protect against a low frequency, high severity event. Ordinarily, capital is held in an amount sufficient to fund a firm's activities. When additional capital is held only for the purpose of protecting against a low frequency, high severity event, an insurer must charge sufficient premiums to give the capital providers a sufficient rate of return. ${ }^{187}$ This results in premiums that can be much higher than the expected loss.

A stylized example illustrates the point. First consider high frequency, low severity risks. Assume the expected cost is 500 with a range of 400 to 600 , an investment yield of $8 \%$ on premiums, a tax rate of $25 \%$ no overhead costs, and a cost of capital of $15 \%$, which is the rate of return that capital providers expect. The insurer charges a premium of 500 and maintains capital of 100. Thus, premium and capital can cover losses at the high end of the range of expectations (600) and ensure claims payment and solvency of the firm. Losses are highly frequent and in small amounts. With even distribution of losses and claims paid throughout the year, the premium of 500 earns pretax investment income of $20(=500 \div 2 \times 8 \%)$, with net profit of 15 on capital held of 100 . This meets the $15 \%$ cost of capital. When a risk is high

11; see Emmett J. Vaughan \& Therese Vaughan, Fundamentals of Risk and InsurANCE 17-18 (9th ed. 2003) (discussing risk retention).

182. HaRrington \& Niehaus, supra note 169, at 11.

183. Id.

184. See Robert J. Rhee, Terrorism Risk in a Post-9/11 Economy: The Convergence of Capital Markets, Insurance, and Government Action, 37 ARIZ. ST. L.J. 435, 474-78 (2005) (discussing the economic feasibility of insuring catastrophic risks).

185. See Scott E. Harrington \& Greg Niehaus, Government Insurance, Tax Policy, and the Affordability and Availability of Catastrophic Insurance, 19 J. INS. REG. 591 (2001); see also Cong. Budget Office, Federal Reinsurance for Disasters 3 (2002) (discussing the insurability problem of catastrophic risks).

186. Eric Briys \& François de Varenne, Insurance: From Underwriting to DeRIVATIVES 6 (2001).

187. Rhee, supra note 184 , at $474-76$; see Harrington \& Niehaus, supra note 185 , at 595-99. 
frequency and low severity per these assumptions, policyholders pay 500 of premium for an expected loss of 500, which is a premium-to-expected loss ratio of $1: 1 .^{188}$

Now consider low frequency, high severity risks. The risk is a 1-in-20 year event with a loss of 10,000. The actuarial risk in any given year is 500, but the insurer must hold capital of 10,000 to ensure claims payment and solvency. If the insurer charges the expected actuarial loss of 500 as premium, the pretax investment income is 40 and net profit is $30 .{ }^{189}$ The premium is earned profit since in most years there are no claims, and after taxes the earned premium yields an additional profit of 375 . Total profit on underwriting and investment is 405 , which is a paltry $4.05 \%$ return on a capital of 10,000 . To earn a $15 \%$ rate of return, the insurer must have a net profit of 1,500 . The net income deficiency of 1,095 (or $10.95 \%$ additional required return) must be recovered through additional premiums charged. This requires an additional premium of 1,352 on top of the 500 actuarial loss. ${ }^{190} \mathrm{~A}$ total premium of 1,852 yields net investment income of 111 and net underwriting profit of 1,389 , for a total net profit of 1,500 , which is a $15 \%$ return on capital of 10,000 . When a risk is low frequency and high severity per these assumptions, policyholders pay 1,852 of premium for an expected loss of 500, which is a premium multiple of $3.7 x$ expected loss. Economically feasible risk transfer rationally occurs at multiples of the expected value of the loss. The price of transferring catastrophic risk is high.

Insurance economists have shown that as risk decreases in frequency and increases in severity, premiums increase nonlinearly. The figure below shows this effect. ${ }^{191}$

188. In the actual world, premiums cannot be $1: 1$ because there would be a loading charge, which would include expenses. See supra note 169.

189. It is not 20 as in the previous example because the premiums are not being paid back to policyholders in most years as claims paid.

190. This is calculated as follows: $1,095=\mathrm{P} \times(1-.25)+\mathrm{P} \times(.08 \times(1-.25))$. When this equation is calculated, premium $\mathrm{P}=1,352$.

191. See Harrington \& Niehaus, supra note 185, at 598 fig.1. 
FiguRE 1

Premiums as a Nonlinear Function of Risk

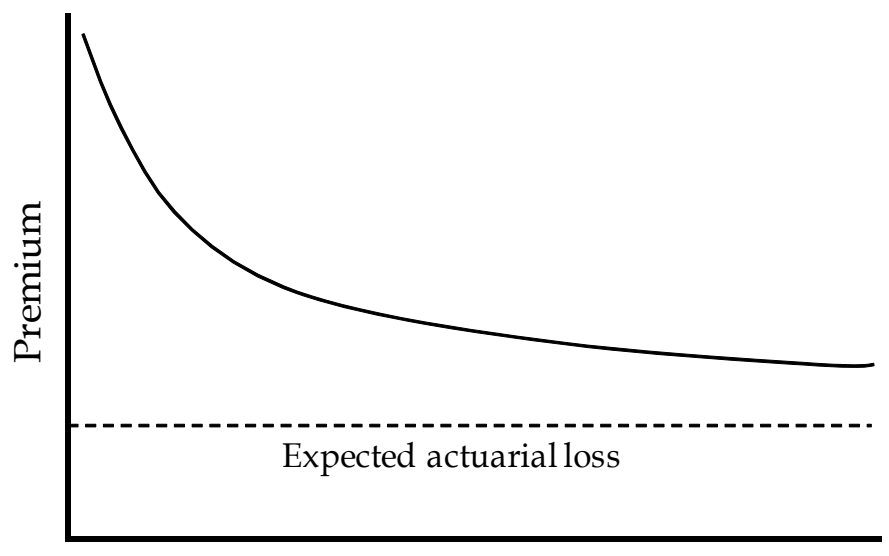

Probability of Loss

Since premium represents the price of risk transfer, it represents the financial cost of bearing catastrophic risk. Expected value and risk are different. When risk is transferred through the insurance mechanism, it must be priced. The more catastrophic the risk, the more insurers must charge premiums that are greater than the actuarial loss. Catastrophic risks have significant implications for the financial and operational aspects of a firm that must either retain the risk or self-insure. The transfer of punitive damages liability to an insurer is at best uncertain. ${ }^{192}$

Outlier negative outcomes increase the probability of financial distress, which imposes significant financial and economic costs on the corporation's constituencies. In addition to substantial professional fees and transaction costs, ${ }^{193}$ financial distress such as bankruptcy disrupts a firm's operations and creates real and significant economic costs arising from lost profits, operational disruptions, and express and implicit rearrangement of contractual relationships with suppliers and customers. ${ }^{194}$ Beyond the prospect of insolvency, outlier judgments increase the variance of profit and loss. Greater

192. See supra notes $179-180 \&$ accompanying next.

193. The out-of-pocket transaction cost in a bankruptcy is in the range of 3 to 7 percent of the firm value. See Jerold B. Warner, Bankruptcy Costs: Some Evidence, 32 J. FIN. 337 (1977); Lawrence A. Weiss, Bankruptcy Resolution: Direct Costs and Violation of Priority of Claims, 27 J. FIn. ECON. 285 (1990); James S. Ang et al., Note, The Administrative Costs of Corporate Bankruptcy, 37 J. FIN. 219 (1982).

194. See Edward I. Altman, A Further Empirical Investigation of the Bankruptcy Cost Question, 39 J. FIN. 1067, 1077 (1984) (reporting lost profits to be 12.2 percent and 23.7 percent of firm value for retail and manufacturing firms); $c f$. David Sunding \& David Zilberman, Consideration of Economics Under California's Porter-Cologne Act, 13 Hastings W.-N.W. J. Envtl. L. \& Pol'y 73, 91 (2007) (“At present, economic theory does not suggest totally satisfactory, formal measurements of the economic costs of insolvency."). 
variability of returns increases the firm's cost of capital since the investment opportunity is riskier. Litigation-induced increases in the firm's cost of capital diminish the company's stock value. ${ }^{195}$ This decline in stock value is a real financial cost that stockholders and perhaps even creditors and employees of the firm bear.

The cost of catastrophic risk is factored into the value of settlements. The argument is that the threat of catastrophic liability creates "settlement pressure." Proponents of restricting punitive damages claim that settlements are overvalued because, fearing an outlier verdict from an out-of-control jury, corporations will settle at a high price. ${ }^{196}$

We see an example of how catastrophic litigation risk affects settlement value and litigation behavior in In re Rhone-Poulenc Rorer Inc. ${ }^{197}$ The district court there certified a plaintiff class where the plaintiffs averred that the defendant manufacturer had infected them with HIV-tainted blood products. ${ }^{198}$ The Seventh Circuit reversed the district court's certification with Judge Richard Posner noting that a class action would substantially increase "the sheer magnitude of the risk." 199 In an aggregate action, the turn of fortune on a single outcome magnifies variance and exposes the corporation to great risk. A defendant cannot smooth out the risk by holding a portfolio of cases, and instead total liability depends on "the outcome of a single jury trial." ${ }^{200}$ Since a one-shot bet can put a corporation in danger of insolvency, the corporation may not wish to stake its existence on a single outcome. ${ }^{201}$ The corporate defendant is then put "under intense pressure to settle." ${ }^{202}$ For these reasons, the court in Rhone-Poulenc held that the determination of liability should "emerge from a decentralized process of multiple trials, involving different juries, and different standards of liability, in different jurisdictions, ${ }^{203}$ necessitating a decertification of the class in favor of individual trials. ${ }^{204}$

195. See David M. Cutler \& Lawrence H. Summers, The Costs of Conflict Resolution and Financial Distress: Evidence from the Texaco-Pennzoil Litigation, 19 RAND J. Econ. 157, 169-70 (1988).

196. See Koenig, supra note 29, at 172-73 ("Tort reformers blame punitive damages for inflating settlements of dubious claims, a social cost ultimately borne by corporations, consumers, employees and stockholders.”); Polinsky, supra note 29, at 671 (“[E]ven if punitive damage awards at trial are on average insignificant, it does not follow ... that the effect of punitive damages on settlement is minimal as well.”).

197. 51 F.3d 1293 (7th Cir. 1995).

198. Rhone-Poulenc, 51 F.3d at 1296.

199. Id. at 1297 .

200. Id. at 1299 .

201. See Viscusi, supra note 17, at 285 (noting that punitive damages "may pose a catastrophic threat of corporate insolvency").

202. Rhone-Poulenc, 51 F.3d at 1297-98.

203. Id. at 1299 .

204. In another article, I criticize the holding in Rhone-Poulenc because, among other things, "as a matter of equity and fairness, it is unclear why corporate defendants or their shareholders are entitled to judicial protection from the adverse valuational effects of risk" 
The sensitivity to aggregate risk seen in Rhone-Poulenc suggests a direct connection between catastrophic risk and economic value. A class action is similar to an outlier punitive damages award in that both can impose catastrophic liability. When faced with a catastrophic liability, a corporate defendant can manage the risk by eliminating the risk. Settlement eliminates litigation risk. In effect, a defendant pays a premium to eliminate the risk of a "small probability of an immense judgment," 205 which is predicted by and consistent with financial economic principles. ${ }^{206}$ Since settlement is an essential aspect of the tort and litigation systems, these factors of value must also affect the theory of punitive damages.

The key point is this: the pricing of catastrophic risk in the insurance market reflects the true economic cost of retaining catastrophic risk. A corporation cannot avoid this cost. If it seeks to eliminate this risk, it must pay the plaintiff a risk premium at settlement. If it retains this risk, the risk will manifest in the valuation of the firm. The valuational considerations of catastrophic legal risk are discussed in the next Section.

\section{Case Studies of Texaco-Pennzoil and BP's Gulf Oil Spill}

The financial distress associated with punitive damages is illustrated by the famous case of Pennzoil v. Texaco. ${ }^{207}$ In 1984, Pennzoil filed an action for tortious interference with contract, claiming that Texaco by acquiring Getty Oil had interfered with Pennzoil's prior contract to purchase Getty Oil stock. ${ }^{208}$ On November 19, 1985, a Texas jury returned the largest verdict in the history of American litigation: $\$ 7.53$ billion in compensatory damages and $\$ 3$ billion in punitive damages. ${ }^{209}$ Subsequently, Texaco filed for bankruptcy, and the case eventually settled for $\$ 3$ billion in cash. ${ }^{210}$ Although this case involved a substantial absolute amount of punitive damages, the multiple was only $0.4 \mathrm{x}$. The more important point is that the combined compensatory and punitive awards were so substantial relative to even Texaco's wealth that it imposed financial distress on the firm.

This case teaches an important lesson about the economic cost of catastrophic legal liability. David Cutler and Lawrence Summers computed the abnormal stock market returns of Texaco and Pennzoil during the litigation period. ${ }^{211}$ Their computations showed that the litigation reduced the com-

when single-shot individual plaintiffs always confront the same problem. Rhee, supra note 35 , at 153 .

205. Rhone-Poulenc, 51 F.3d at 1298.

206. See generally Rhee, supra note 15 (analyzing how parties account for different perceptions of risk in valuation); Rhee, Price Theory of Legal Bargaining, supra note 26 (applying financial economics to construct a pricing theory of legal disputes).

207. See Cutler \& Summers, supra note 195; Mnookin \& Wilson, supra note 33.

208. Mnookin \& Wilson, supra note 33, at 296.

209. Id.

210. Id. Mnookin and Wilson provide a detailed history of the case. Id. at 300-09.

211. Cutler \& Summers, supra note 195. 
bined value of the two companies by $\$ 3.4$ billion, over 30 percent of the companies' joint pre-dispute value. ${ }^{212}$ For every one dollar lost by Texaco, Pennzoil gained only 40 cents. ${ }^{213}$ This value "leakage" was directly caused by the litigation. ${ }^{214} \mathrm{~A}$ large portion of this loss was restored when the case finally settled. ${ }^{215}$

The chart below records the five-day valuational effects of news regarding the litigation and settlement events on the combined value of the two companies throughout the litigation period. ${ }^{216}$ In theory, a lawsuit is a zerosum game, disregarding transaction cost. The joint value of the two should decrease only by the amount of transaction cost. However, the chart below shows that the litigation was not a zero-sum game. It instead destroyed economic value as measured by the sum value of the two companies. ${ }^{217}$

212. Id. at 158 .

213. Id.; see also Sanjai Bhagat et al., The Costs of Inefficient Bargaining and Financial Distress: Evidence from Corporate Lawsuits, 35 J. FIN. ECON. 221, 228 (1994) (confirming similar results); Kathleen Engelmann \& Bradford Cornell, Measuring the Cost of Corporate Litigation: Five Case Studies, 17 J. Legal Stud. 377 (1988) (same).

214. Cutler \& Summers, supra note 195, at 158.

215. Id.

216. See id. at 164 fig.1.

217. The data used are from tables 1 and 2 in the Cutler and Sumners article, and use the "Five Days After Announcement" combined value figures. Id. at 161-62. The Cutler and Summers article has a small, insignificant computational error in table 1 . The total value lost in connection with the litigation events sum to $\$ 4,291.5$ million, and not $\$ 4,199.5$ million as reported in the Cutler and Summers article. This Article uses the correct figure. 
FiguRE 2

\section{Effect of Litigation Events on Texaco and Pennzoll's Combined Value}

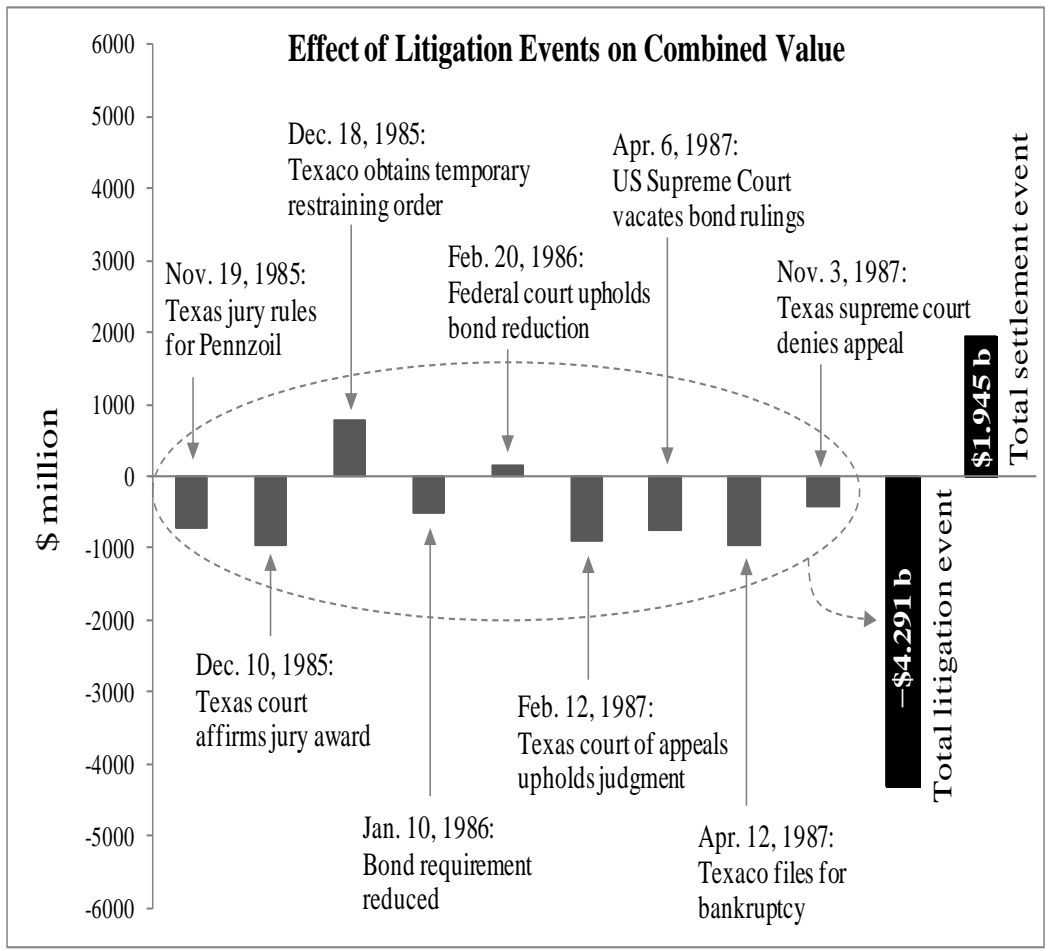

This chart shows that collectively, litigation news reduced the value of the combined firms by $\$ 4.291$ billion. This compares to the $\$ 1.945$ billion gained from settlement news.

Cutler and Summers concluded that most of the lost economic value was not attributable to the transaction cost of litigation. ${ }^{218}$ Instead, the lawsuit involved potential liability that could cause Texaco financial distress (and eventually the company did file for bankruptcy). What caused the economic loss then? The simple answer is this: the uncertainty and unpredictability of the lawsuit imposed a cost of financial distress, arising from an increase in Texaco's cost of capital, which could not be captured in a concomitant decrease in Pennzoil's cost of capital. ${ }^{219}$ "Although the payment of a judgment is always zero sum, the valuational considerations are not necessarily so. In

218. Cutler and Summers concluded that "legal disputes can impose large costs on a firm, and that the indirect effects of conflict on profitability can be substantially greater than the direct expense of the litigation." Id. at 170; see also Bhagat et al., supra note 213, at 22223 ("Indirect costs of financial distress, in contrast, are potentially more important [than the direct costs, such as legal and other administrative fees].").

219. Rhee, Price Theory of Legal Bargaining, supra note 26, at 663. 
the public market at least, uncertainty creates a cost that was not captured as a surplus by the opposing side."220

Another case study illustrating the effects of catastrophic liability risk and the cost of financial distress is the BP Deepwater Horizon accident. On April 20, 2010, the offshore oil rig, Deepwater Horizon, which was leased by British Petroleum ("BP"), exploded and caused the largest oil spill in history. ${ }^{221}$ As the magnitude of the disaster became apparent, the market value of BP's stock plummeted. In the stock price chart below, I have compared BP's stock price to a composite index of peer oil companies for the two-year period from August 2009 to August 2011.222

FiguRe 3

\section{Comparison of BP's Stock Price to Composite Index of PeER Oil Companies}

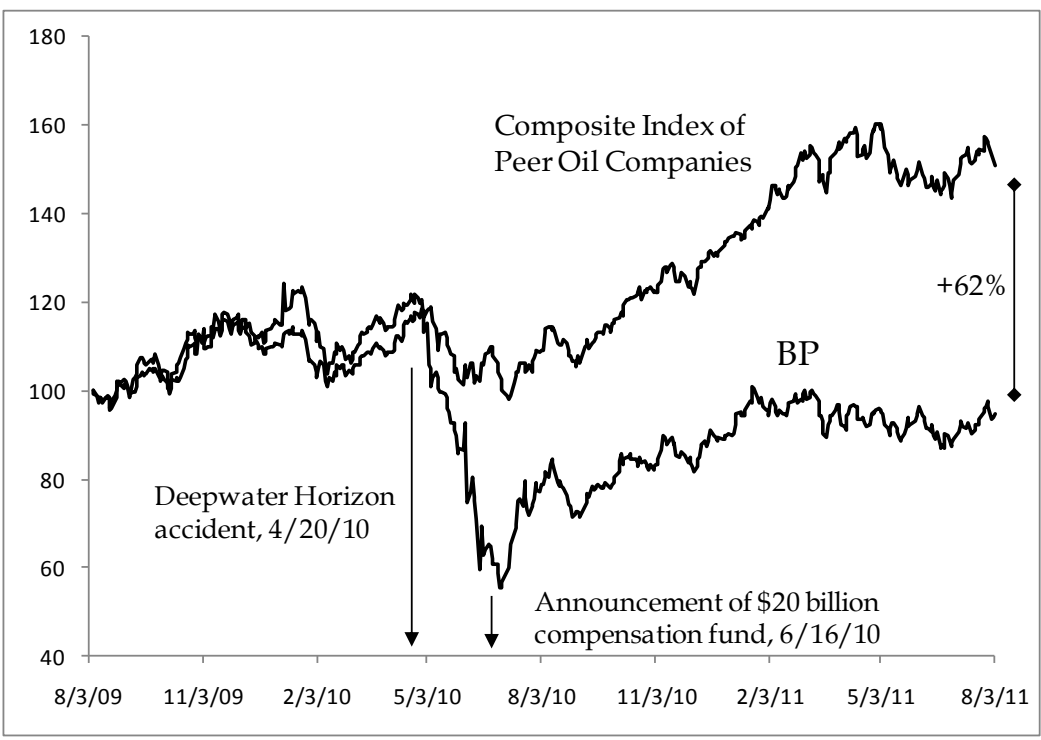

Before the accident, BP's stock price had been highly correlated to the stock prices of its peers. After the accident, BP's stock value declined precipitously as the market anticipated catastrophic legal liability. BP's stock price became less correlated with and more decoupled from its peer group.

220. Id

221. Tom Zeller Jr., Estimates Suggest Spill Is Biggest in U.S. History, N.Y. Times, May 28, 2010, at A15, http://www.nytimes.com/2010/05/28/us/28flow.html.

222. The peer companies are ExxonMobile (XOM), ConocoPhillips (COP), Royal Dutch/Shell (RDS-A), and Chevron (CVX). The stock prices of BP and its peers were indexed to a common baseline of 100, and the percent increases and decreases were tracked over time. The composite index was not weighted for market capitalizations but instead is a simple average of the peer group. 
The market was factoring legal liability and cleanup cost into the stock price. However, the stock price also included a risk premium for the possibility that liability and cleanup could exceed BP's net worth resulting in insolvency. ${ }^{223}$

The slide in the stock price abated when BP announced on June 16, 2010 , that it had established a $\$ 20$ billion compensation fund to pay claims in lieu of legal action. ${ }^{224}$ The compensation fund is not capped at $\$ 20$ billion, ${ }^{225}$ and it does not preclude plaintiffs from filing suit. ${ }^{226}$ Following the announcement, however, the stock price increased and once again correlated to the peer group. Why? Because the compensation fund established a soft floor on liability. The mass elimination of legal actions implied by the enormous fund amount suggested that much of the catastrophic risk of legal liability had been removed. Like the September 11 Victim Compensation Fund established almost a decade earlier, perhaps the sentiment was that most victims of BP Deepwater Horizon would choose the speedy, administratively simpler option provided by the compensation fund. ${ }^{227}$

Nevertheless, BP's stock price continued to suffer from a substantial discount to its peers. As of August 3, 2011 (an arbitrary cutoff date for the analysis here), BP's peers enjoyed a $62 \%$ valuation premium to BP's stock price, which closed at $\$ 43.18$. As of that date, BP had a market capitalization of approximately $\$ 136$ billion. ${ }^{228}$ Assume that Deepwater Horizon did not spill oil and that BP's stock price correlated tightly to its peer group as it had done before the accident: if so, BP's market capitalization would have been around $\$ 220$ billion. Thus, the difference between BP's implied value and its actual value was $\$ 84$ billion, a loss which is attributable to the accident.

BP's compensation fund is $\$ 20$ billion with an additional commitment of funds if this amount proves insufficient to cover all claims. BP must also

223. Before the establishment of the compensation fund, there were speculations that BP could be forced into bankruptcy or be acquired in a hostile takeover. See Andrew Ross Sorkin, Imagining the Worst in BP's Future, N.Y. Times, June 8, 2010, at B1.

224. Press Release, BP, BP Establishes \$20 Billion Claims Fund for Deepwater Horizon Spill and Outlines Dividend Decisions (June 16, 2010), available at http://www.bp.com/ genericarticle.do?categoryId $=2012968 \&$ contentId $=7062966$.

225. Id. ("The fund does not represent a cap on BP liabilities, but will be available to satisfy legitimate claims.").

226. The numerous lawsuits have been consolidated in a multidistrict litigation. See U.S. District Court-Eastern District of Louisiana, MDL-2179 Oil Spill by the Oil Rig "Deepwater Horizon," http://www.laed.uscourts.gov/OilSpill/OilSpill.htm (last updated Mar. 14, 2012).

227. See Lloyd Dixon \& Rachel Kaganoff Stern, RAND Inst. for Civil Justice, COMPENSATION FOR LOSSES FROM THE 9/11 AtTACKS 24-25 (2004) (noting that 2,879 claims out of 2,976 deaths (representing 97 percent) were filed with the 9/11 fund). The BP Deepwater Horizon Disaster Victim Compensation Fund is administered by Kenneth Feinberg, the same administrator of the September 11 Victim Compensation Fund. Id. at 19.

228. As of June 30, 2011, BP had shares outstanding of 3.156 billion shares. Share Buyback and Shares in Issue, BP, http://www.bp.com/extendedsectiongenericarticle.do? categoryId=9000533\&contentId=7001189 (last visited Mar. 18, 2012). 
bear the cost of cleanup. The company has set aside over $\$ 40$ billion for compensation and cleanup, ${ }^{229}$ which one assumes is the company's best guess at the value of the total loss. Yet the market is discounting the company's value by another $\$ 44$ billion. Much of the lost value is attributable to the uncertainty surrounding the total liability. Since the market cannot predict with precision what the total amount will be, it factors in a substantial risk premium.

BP's stock value loss illustrates the financial and economic effects of catastrophic loss and risk on a corporate defendant. Punitive damages can impose the risk of catastrophic loss on a firm. This creates uncertainty, and it may require the payment of a large risk premium by a defendant. To the extent that this risk premium does not serve a deterrence purpose, it creates a situation in which the legal action is overvalued and thus the defendant is overdeterred.

\section{Toward Optimal Liability and Deterrence}

\section{A. Arbitrage and Efficient Pricing}

Part III shows that different risk exposures create antipodal, systematic risk arbitrage opportunities: arbitrage in favor of defendants when the risk is ordinary, and arbitrage in favor of plaintiffs when the risk is catastrophic. In the former, there is liability leakage and thus underdeterrence. In the latter, there is excess liability and thus overdeterrence. Plaintiffs are justified in arguing for unconstrained punitive damages, and defendants are justified in arguing for restraint. An economic theory of punitive damages must balance these tensions.

In financial economics, the principle of no arbitrage states that sustained arbitrage opportunities should not exist in an efficient market. ${ }^{230}$ Once a price discrepancy is found, an arbitrageur makes riskless profit by buying or selling an underpriced or overpriced asset. When the price discrepancy becomes known in the market, the price corrects and the arbitrage opportunity disappears. Asset prices are efficient in the sense that they reflect the market view of intrinsic value.

Sustained exploitation of arbitrage undermines efficiency in capital markets and in the tort system as well. If the tort and litigation systems are pricing mechanisms to determine the value of harmful activities and legal actions, prices at efficient levels yield optimal deterrence. The existence of risk arbitrage opportunities in litigation produces inefficient outcomes. The policy goal should be to eliminate arbitrage opportunities and maintain effi-

229. Graeme Wearden, BP Profits Dip as Deepwater Horizon Costs Continue to Mount, GuARDian (U.K.), Apr. 27, 2011, http://www.guardian.co.uk/business/2011/apr/27/bp-profitsdip-deepwater-horizon-costs (reporting that BP has set aside $\$ 40.9$ billion to pay for the environmental disaster); see also Sorkin, supra note 223 (noting that "something approaching $\$ 40$ billion is not out of the question" for compensation and cleanup).

230. BREALEY ET AL., supra note 14 , at 38 . 
cient prices in the tort system. Since the two categories of risk (ordinary and catastrophic) are the key variables in producing antipodal effects on optimal deterrence, different approaches are needed to mitigate risk arbitrage in these different classes of cases.

\section{B. Mitigating Risk Arbitrage in Ordinary Cases}

In most ordinary cases, the Campbell- or Baker-type of limit on punitive damages makes no sense because it preserves the corporate defendant's risk arbitrage and thus undermines optimal deterrence by systematically producing undervalued cases. Empirical evidence has confirmed the nonnecessity of such limits in most ordinary cases. Punitive damages are not at play because the level of conduct does not merit an award. A defendant is most susceptible to punitive liability when he engages in intentional torts, fraud, discrimination, or economic wrongs. ${ }^{231}$ Punitive damages are usually not granted in ordinary negligence actions. Even when they are granted, the level of liability is ordinary.

To the extent that punitive damages are at issue, they help to offset a corporate defendant's risk arbitrage opportunity. While a defendant typically is less risk averse, has a lower opportunity cost, and can mitigate the variance of an individual outcome due to portfolio diversification, ${ }^{232}$ the threat of punitive damages increases the defendant's risk profile. This increase in risk helps to eliminate the otherwise asymmetric risk profile. Consistent with the arguments advanced by tort reformists and business interest lobbyists, ${ }^{233}$ plaintiffs gain an advantage at settlement in claiming punitive damages.

Plaintiffs' attorneys acknowledge that punitive damages claims provide important leverage to their clients. In interviews, many litigators maintained that the defense would not come to the bargaining table with "a fair settlement" unless punitive damages were a real possibility. ... Attorneys prosecuting securities fraud cases maintain that punitive damages are key to just and prompt settlement. These lawyers argue that if defendants do not face the possibility of a large punitive damages verdict, corporations have little or no incentive to settle for fair compensatory damages. ${ }^{234}$

These empirical observations are widely known to litigating parties and their lawyers and are predicted by this Article's risk-based financial economic analysis of the relationship between settlement and punitive damages. ${ }^{235}$

231. At least since 1960, there has been a proliferation of punitive awards based on reckless vis-à-vis malicious conduct. Sharkey, supra note 17 , at 364 . This development supports the nonretributive rationale for punitive damages. Id. at 364-65.

232. See supra Section III.B.

233. See supra note 178 and accompanying text.

234. Koenig, supra note 29, at 176.

235. See supra Part III. 
When the level of compensatory damages is low, there is good reason not to cap punitive damages until they reach the point of causing financial distress. While the standard law and economics theory suggests that punitive damages should be capped at the level of escaped liability for wrongful conduct, this rule may nevertheless result in underdeterrence in a dispute resolution system in which most actions are privately settled. An example illustrates the point. Assume that the harm is 200, a low amount relative to the defendant's wealth, and the probability of detection is $11 \%$, a fairly low detection rate. The parties are aware that punitive damages are capped by the standard law and economics rule. The parties also agree on the prospects for the outcome of the case: the probability of liability is $50 \%$, and on a plaintiff win the probability of a punitive damages award is $50 \%$. The expected value of trial is $500,{ }^{236}$ which produces the optimal level of liability based on the probabilities of detection and trial and the costs of the defendant's activities. However, since the defendant enjoys an asymmetric risk advantage and thus an arbitrage in the pricing of the disputed legal right, a settlement will likely be reached at a lower amount than the expected value. Assume that an average plaintiff would give a discount of $20 \%$, so that the parties settle at 400 . Liability is less than the level of optimal deterrence. The dynamics of settlement undermine the law and economics theory of optimal deterrence.

Assume now that there is no cap on punitive damages. The defendant still expects punitive damages, if assessed, to be fairly low and correlated to the compensatory damages; but now there is a minute risk of an outlier award. Suppose that the outlier award could be as high as $258 \mathrm{x}$ (the kind seen in Gore and Campbell), with a minute $0.1 \%$ probability of the outlier occurring (that is, a 1 in 1,000 chance, or the proverbial lightning strike). Although this liability would be very substantial, it would not cause financial distress (the liability amount may be high but not severe as defined in this Article). The expected value of the outlier case is $51.8,{ }^{237}$ and the expected value of the combined outcomes is $550 .{ }^{238}$ These facts change the dynamics of settlement. The parties must account for a very small but real chance of a high outlier award. The plaintiff may still be willing to concede a $20 \%$ discount, which is a discount of 110 . However, consistent with the risk transfer and catastrophic risk pricing principles seen in Section III.C, the defendant may add a risk premium to the expected value of an outlier award. ${ }^{239}$ For catastrophic risk, this risk premium could be multiples of the

236. This is calculated as follows: No Liability $(50 \% \times 0)+$ Liability $(200 \times 25 \%)+$ Punitive Liability $(1,800 \times 25 \%)=500$. The punitive damage multiple is $8 \mathrm{x}$ based on $(1 / 11 \%$ $-1)$.

237. This is calculated as follows: $(258 \times 200+200) \div 1,000=51.8$.

238. This is calculated as follows: No Liability $(0 \times 50 \%)+$ Liability $(200 \times 25 \%)+$ Punitive Liability $(1,800$ x 249/1,000) + Outlier Punitive Liability [(258 x $200+200) \div 1,000]$ $=550$.

239. Anecdotal evidence from insurance claims settlement practices supports the view that even insurance companies add a premium to expected value to eliminate the risk of outlier awards. Laurence Ross observed that insurance companies may offer "danger value," which is 
expected value. Suppose that the risk premium is $116 \%$ of the expected value of the outlier, or 60. Absent this risk premium, settlement would occur at 440 due to the plaintiff's concession of a discount. But with the risk premium added to account for the risk of the outlier, it would occur at 500, the level required for optimal deterrence.

I do not suggest that in practice the numbers work out in these exacting ways. The point is not that settlements can take place with such mathematical precision, but instead it is to show that the effects of discount and premium tend to offset in a way that minimizes a corporate defendant's risk arbitrage. If minute risks of outliers were introduced into the settlement calculus, valuations at settlement would approach risk-neutral levels. Thus, even a very small risk of an outlier award can advance the goal of optimal deterrence in ordinary cases by offsetting a corporate defendant's risk arbitrage opportunity.

Based on the considerations in this Section, the rule of punitive damages should be this: when compensatory damages are low relative to the defendant's wealth and the expected liability is ordinary, there should be no cap on punitive damages up to the point at which total liability resulting from a high punitive damages multiplier produces financial distress. In this way, a corporate defendant's risk arbitrage opportunity would be offset by the risk premium that the plaintiff would concede at settlement to eliminate (insure against) the prospect of a highly variable cash flow arising from the litigation process.

\section{Mitigating Risk Arbitrage in Catastrophic Cases}

In the infrequent cases of potentially extreme liability, the risk arbitrage opportunity flips to the plaintiff's advantage and thus undermines optimal deterrence by systematically producing overvalued cases. Facing potentially extreme liability with the threat of financial distress or insolvency, a firm will want to eliminate this risk and so will pay a hefty risk premium. The firm will thus settle the claim, and the settlement value will favor the plaintiff who can use the threat of extreme liability as leverage. The risk premium a defendant pays constitutes the economic cost associated with the risk of financial distress. In these cases, defendants need special protection.

The cost of the risk premium is incurred whether the corporate defendant settles or not: in settlement, it is paid in cash as the settlement amount; otherwise, the cost is reflected in the firm's valuation. From a corporate finance perspective, in the absence of settlement, the firm's cost of equity will increase due to the increased probability of bankruptcy, while the value of the firm, including the value of the equity and debt held by the firm, will decrease. From a larger perspective, the efficient capital markets hypothesis suggests that information concerning legal liability is incorporated into the

a premium in excess of the expected value, to eliminate exposure to a potentially severe jury verdict. Laurence Ross, Settled Out of Court: The Social Process of Insurance Claims Adjustments 202 (1970). 
price of the security. ${ }^{240}$ The weak form of the hypothesis, generally considered valid, suggests that all past information has been incorporated into the current security price. ${ }^{241}$ The effect of information, positive or negative, can be offset by the disclosure of other information, but the prior information concerning the tort action in question is embedded in the security price. The loss of value is real and is suffered by the firm's shareholders and creditors.

The cost of risk transfer in settlement and the economic cost of financial distress are real and borne by the firm. To the extent that this premium exceeds the expected value of the harm and any potential escaped liability, defendants are overdeterred. An economic theory of punitive damages must credit this cost in the calculus of optimal deterrence.

Obviously, compensatory damages are fair game in torts, and financial distress is no reason to reduce the amount of compensatory damages. ${ }^{242} \mathrm{~A}$ tortfeasor must pay for all harms inflicted on the plaintiff for its wrongful acts. However, punitive damages do not compensate; they are meant to punish a defendant on a discretionary basis. They should not impose substantial financial distress. If a corporation, or any tort defendant for that matter, was entitled to Eighth Amendment protection with respect to punitive damages in a tort action among private parties, ${ }^{243}$ the imposition of financial distress or insolvency could very well constitute excessive punishment. Applying standard law and economics theory, one could argue that punitive damages should be applied to a firm anytime it escapes liability. However, when compensatory damages are high, the chances are that the conduct in question is an unfortunate one-off transaction. Even if there is the chance of escaped liability from other transactions, we intuit that the economic cost of financial distress and social cost of insolvency are far greater than the adverse effect of escaped liability on incentives.

The rule against financial distress can be illustrated by a simple budget line.

240. See Eugene F. Fama, Efficient Capital Markets: A Review of Theory and Empirical Work, 25 J. FIN. 383 (1970) (setting forth the different forms of efficiency); Ronald J. Gilson \& Reinier H. Kraakman, The Mechanisms of Market Efficiency, 70 VA. L. REv. 549, 554-55 (1984) (discussing the efficient capital market hypothesis).

241. Frank J. Fabozzi \& Franco Modigliani, Capital Markets: Institutions and INSTRUMENTS 291 (4th ed. 2009).

242. Corporations and other limited liability entities enjoy the benefit of limited liability, which ensures that a portion of the harms created are externalized to tort victims. See Hansmann \& Kraakman, supra note 137, at 1916-23; Rhee, supra note 137, at 1433-35.

243. See Browning-Ferris Indus. of Vt., Inc. v. Kelco Disposal, Inc., 492 U.S. 257, 263 64, 275 (1989) (holding that the Eighth Amendment does not apply in a civil action for money damages among private parties); id. at 285 (O'Connor, J., concurring in part and dissenting in part) (joined by Justice Stevens) (arguing that the Eighth Amendment should apply to corporations). 
FiguRE 4

Budget Line For Legal Liability

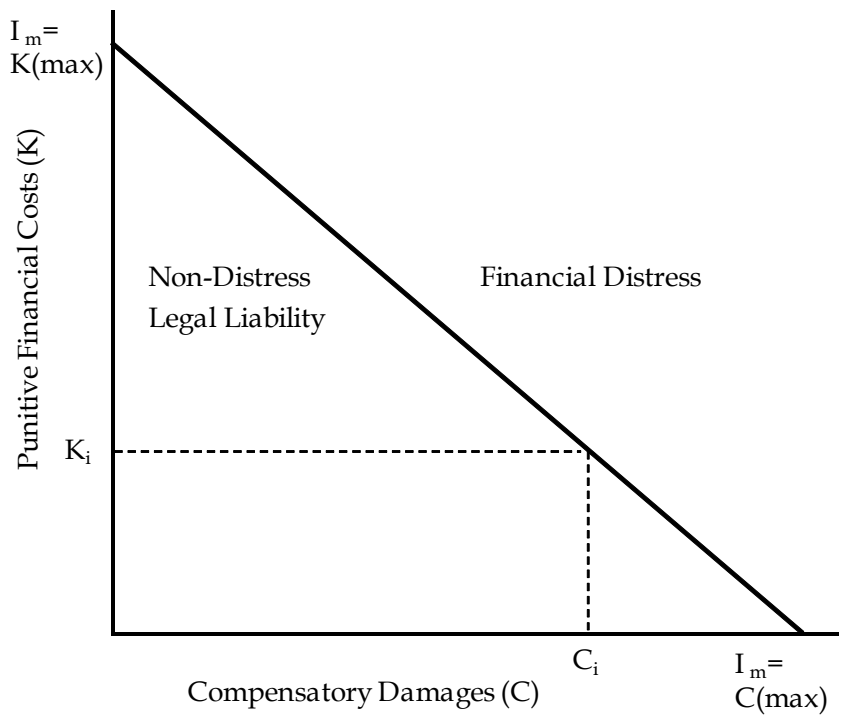

The amount of liability $I$ is the line that divides financial nondistress from financial distress. We note that $K$ is the punitive financial cost, which is the total economic cost of punitive damages having two components: (1) the legal award of punitive damages $P$, which is a cash amount, and (2) the financial economic cost $F$ associated with the legal action, which is a noncash economic cost borne by the defendant including a risk premium at settlement, an increase in the cost of equity, and the cost of bankruptcy.

The line dividing nondistress and distress is marked by two endpoints, high punitive damages and high compensatory damages. It demarcates the budget line for the maximum imposable punitive financial costs: nondistress is defined as the interval $\left[0, \mathrm{I}_{\mathrm{m}}\right]$. This suggests that with nominal compensatory damages, $\mathrm{I}_{\mathrm{m}}=\mathrm{K}(\max )$, and with no punitive damages, $\mathrm{I}_{\mathrm{m}}=\mathrm{C}(\max )$. At any given point in the interval $\left[0, \mathrm{I}_{\mathrm{m}}\right]$, we can state the liability amount that would not impose financial distress as: $\mathrm{I}_{\mathrm{i}}=\mathrm{K}_{\mathrm{i}}+\mathrm{C}_{\mathrm{i}}$.

Another way to state the proposed rule is this: when compensatory damages are more than nominal, punitive damages should be capped such that punitive financial costs do not create financial distress. This rule is represented by the expression $\mathrm{P}_{\mathrm{i}} \leq \mathrm{I}-\mathrm{C}_{\mathrm{i}}-\mathrm{F}_{\mathrm{i}}$. Punitive damages are the maximum potential residual liability that can be imposed net of compensatory damages and the financial economic cost associated with the action. ${ }^{244}$

244. This assumes that compensatory damages do not by themselves impart financial distress, and thus $\mathrm{C}<\mathrm{I}$. 
The proposed rule has several implications arising from the three ways in which liability can reach the zone of financial distress.

1. The case of extreme compensatory damages. For a corporation, cases of extreme compensatory damages typically involve megatorts or mass torts such as the Exxon oil spill in Prince William Sound, BP's Deepwater Horizon incident, and the Texaco-Pennzoil incident. Many class actions also fall into this category. In these cases, the issue of punitive damages is really subordinate to the larger issue of compensation, though punitive damages can exacerbate the defendant's financial situation and may constitute the marginal increase in liability that begets insolvency.

When compensation is so large that it threatens financial distress, the punitive financial costs tend to outweigh any of the benefits from imposing punitive damages. The rationale for punitive damages largely dissipates for several reasons: (1) such claims are hard-pressed to escape detection and accountability, (2) compensation alone fully internalizes the cost of wrongful conduct, and (3) the size of the compensation claim and the resulting settlement pressure tend to eliminate a defendant's risk arbitrage.

The Supreme Court intuited this concept when it suggested in Campbell that if compensatory damages are substantial, perhaps only a multiple of $1 \mathrm{x}$ can satisfy due process. ${ }^{245}$ Also, the same rationale likely guided the Court's decision in Baker, which would serve to explain the $1 \mathrm{x}$ multiple rule in maritime cases. To the extent that the intuition is to limit punitive damages when a defendant must pay high compensatory damages relative to its wealth, the Court's reasoning is well founded on the theory that the costs of financial distress outweigh any deterrence (or even retributive) rationale, particularly when the defendant will already be paying a high price for its wrongful conduct.

Cases involving extreme compensatory damages may require more judicial intervention and constraints on the jury. Empirical scholarship has shown that the amount of punitive damages is correlated to the amount of compensatory damages. ${ }^{246}$ If the size of compensatory damages is an indication of the harmfulness of the defendant's conduct, the correlation is rational. At a certain point, however, compensatory damages become so large relative to the defendant's wealth that the commensurate award of punitive damages imposes more costs on the defendant than is justified by the underlying conduct or the possibility of escaped liability. Indeed, escaped liability is most likely not an issue when compensatory damages are large because such disputes are the most likely to be discovered and prosecuted.

2. The case of low compensatory damages and extreme punitive damages. This is the Gore-type case where the compensatory damages are low but the multiple is very high, resulting in an extreme amount of punitive damages relative to the amount of compensatory damages. Also, as in Gore,

245. State Farm Mut. Auto. Ins. Co. v. Campbell, 538 U.S. 408, 425 (2003).

246. "Far from being randomly related, the punitive damages awards increase monotonically with compensatory damages in a statistically significant manner.” Eisenberg et al. 1997, supra note 17, at 639 . 
the amount of punitive damages though extreme in relative terms is not extreme in absolute terms and not within the zone of financial distress. In such circumstances, there is little justification for specially limiting punitive damages beyond the traditional legal standard. The probability of escaped liability is just one consideration. The risk of high punitive damages tends to offset the defendant's risk arbitrage opportunity by imposing more risk on the defendant. However, the potential risk of a high multiple award would not threaten financial distress. In this situation, artificially capping punitive damages would only preserve the corporate defendant's advantages at settlement and thus would tend to underdeter.

A glimpse of this concept is seen in the Supreme Court case law. Although the Court in Campbell set forth a broadly applicable single-digit multiplier cap, it also suggested that larger multiples may be appropriate when compensatory damages are low. ${ }^{247}$ The Court did not explain further, and so some guesswork is needed to determine the contours of this exception. The most plausible construction of the exception is that it is limited to cases with low absolute values of punitive damages. For example, we can hypothesize that a nominal compensatory award of $\$ 1$ may support a 500x multiple for a total liability of $\$ 501$; such liabilities are not the type of awards that have long concerned the Court. The Court is primarily concerned about protecting corporations and preserving its power to regulate judicially the economics of mass-tort liability. ${ }^{248}$ Thus, it may consider suspect the same 500x multiple if it resulted in a liability of $\$ 2,004,000$ against a national corporation, as was the case in Gore. If this is what the Court had in mind - that small dollar value cases do not concern it, but big dollar values do-then the distinction is one without principles and theoretical support. As long as an award of punitive damages is supported by the traditional legal standards as defined under state law, liability should not be limited just because the multiple or the dollar value is high. Such an arbitrary scheme has no sound basis in policy or theory.

3. The case of substantial compensatory and punitive damages. This profile represents the least problematic, most straightforward case. Since punitive damages are in line with compensatory damages, these cases do not run afoul of Campbell. However, while neither substantial compensatory damages nor punitive damages may be sufficient alone to trigger financial distress, the combination could do so. Consistent with the proposed rule here, punitive damages should be constrained sufficiently to prevent financial distress. This means that even punitive damages complying with Campbell's single-digit ratio may result in too much liability.

247. Campbell, 538 U.S. at 425 ("[R]atios greater than those we have previously upheld may comport with due process where a particularly egregious act has resulted in only a small amount of economic damages." (internal quotation marks omitted)); see also BMW of N. Am., Inc. v. Gore, 517 U.S. 559, 582 (1996) ("Indeed, low awards of compensatory damages may properly support a higher ratio than high compensatory awards, if, for example, a particularly egregious act has resulted in only a small amount of economic damages.").

248. See supra Sections I.A, III.A. 
Lastly, I address a potential objection to the proposed rule protecting firms against financial distress: that the proposed rule might incentivize firms to "game" capital structure to their advantage through undercapitalization. This objection is academic and not one of practical significance. As seminal work in financial economics has shown, capital structure is a very important consideration for the value of firms when real-world constraints such as tax policy, bankruptcy, and transaction costs are considered. ${ }^{249}$ Any potential gain from undercapitalization motivated by a desire to avoid punitive damages would be quickly exceeded by the costs associated with a suboptimal capital structure that fails to optimize tax savings, the cost of capital, and the transaction costs of capital raising. The firm's recurring operational and financial needs would outweigh the benefits of a "gamed" capital structure in the event of a nonrecurring, infrequent event like the assessment of a severe punitive damages award.

\section{The Role of Wealth and Administrative Issues}

Not surprisingly, the relevance of the defendant's wealth in calculating the size of a damages award is disputed. Although some courts have suggested that wealth is irrelevant, ${ }^{250}$ many jurisdictions instruct juries that wealth is a relevant factor. ${ }^{251}$ The arguments for and against are well defined. Since money has a marginal utility, plaintiffs argue that appropriate punishment and deterrence are achieved when the defendant's wealth is considered. However, it is easy to see that involving wealth as a factor "invites juries to engage in wealth redistribution and exacerbates the perverse incentives already created by uncertain standards of punitive damage liability." ${ }^{252}$ Many commentators have suggested that wealth should be irrelevant. ${ }^{253}$

249. See Franco Modigliani \& Merton H. Miller, Corporate Income Taxes and the Cost of Capital: A Correction, 53 Am. Econ. Rev. 433 (1963); Franco Modigliani \& Merton H. Miller, The Cost of Capital, Corporation Finance and the Theory of Investment, 48 AM. Econ. REv. 261 (1958).

250. See Kemezy v. Peters, 79 F.3d 33, 35 (7th Cir. 1996) (Posner, J.) (noting that none of the rationales for punitive damages "depends critically on proof [of] the defendant's income or wealth").

251. See, e.g., Pac. Mut. Life Ins. Co. v. Haslip, 499 U.S. 1, 22 (1991) (permitting consideration of defendant's "financial position"); TXO Prod. Corp. v. Alliance Res. Corp., 509 U.S. 443, 492 (1993) (O'Connor, J., dissenting) ("As a historical matter, the wealth of the perpetrator long has been thought relevant."); Ultimate Chem. Co. v. Surface Transp. Int'l, Inc., 658 P.2d 1008, 1012 (Kan. 1983) (same).

252. Dorsey D. Ellis, Jr., Fairness and Efficiency in the Law of Punitive Damages, 56 S. CAL. L. Rev. 1, 63 (1982).

Corporations are mere abstractions and, as such, are unlikely to be viewed with much sympathy. Moreover, they often represent a large accumulation of productive resources; jurors naturally think little of taking an otherwise large sum of money out of what appears to be an enormously larger pool of wealth. Finally, juries may feel privileged to correct perceived social ills stemming from unequal wealth distribution by transferring money from "wealthy" corporations to comparatively needier plaintiffs.

TXO, 509 U.S. at 491 (O’Connor, J., dissenting). 
From the perspective of the standard law and economics model, wealth is irrelevant because it is not a factor in achieving full cost internalization for wrongful conduct. ${ }^{254}$

This Article argues that wealth is relevant for two reasons, both of which are counterintuitive to the way in which wealth has traditionally been understood. First, to the extent that wealth is one factor in a set of criteria that jurors use to assess punitive damages, it tends to increase unpredictability and variance of outcomes. The defendant's wealth is typically understood as a litigation sword wielded by the plaintiff. As a policy matter, the threat of a nonlethal lightning strike positively serves the deterrence function. Wealth as a variable in the calculus of punitive damages tends to create some uncertainty in the outcome. As argued in this Article, some unpredictability and uncertainty is a good thing. This proposition is against the weight of scholarship, and for that matter against the authority of Baker, both of which argue for the virtues of greater certainty and predictability. The defendant's wealth serves an instrumental goal—neutralizing the defendant's risk arbitrage in ordinary cases. Moreover, as other scholars have noted, taking wealth into account is justified by a rational nexus between the utility gained from engaging in harmful conduct and the goal of deterrence.

Second, under the theory advanced in this Article, the defendant's wealth is relevant because it should be a shield against excessive liability. Wealth is the factor that determines the upper boundary of punitive damages. Ordinarily, wealth is seen as a justification, correctly applied or not, for an upward adjustment in punitive damages. But it also defines the limit of punitive damages. In addition to the question of adequate deterrence, evidence of wealth should also be used to protect defendants against excessive punitive damages. The central thesis here is that financial distress should be avoided, and financial distress is a function of the defendant's wealth. The less wealth, the lower the threshold of financial distress, and vice versa.

This Article shows that the intrusion of Gore and Campbell into the policing of punitive damages was largely unwarranted. In most cases, traditional state procedural measures suffice to protect defendants. Wealth should continue to be relevant to the jury's consideration. ${ }^{255}$ However, juries should also be instructed that evidence of wealth, if presented, should be relevant to financial distress, and that financial distress marks the limit of punitive damages. Awards that exceed this limit should be subject to remittur and appellate review.

253. See, e.g., Kenneth S. Abraham \& John C. Jeffries, Jr., Punitive Damages and the Rule of Law: The Role of Defendant's Wealth, 18 J. Legal STud. 415, 415 (1989); Robert D. Cooter, Punitive Damages for Deterrence: When and How Much?, 40 Ala. L. Rev. 1143, 1177 (1989); Polinsky \& Shavell, supra note 17, at 911; Gary T. Schwartz, Deterrence and Punishment in the Common Law of Punitive Damages: A Comment, 56 S. CAL. L. Rev. 133, 140 (1982). But see Jennifer H. Arlen, Should Defendants' Wealth Matter?, 21 J. Legal Stud. 413, 415 (1992) (arguing that there is a deterrence effect on risk-averse defendants).

254. Polinsky \& Shavell, supra note 17, at 911.

255. See supra note 251. 


\section{REASSESSING GORE, CAMPBELL, WILLIAMS, AND BAKER}

In fundamentally reforming the jurisprudence on punitive damages, the Supreme Court was driven by a visceral sense of proper economic proportions. Without a theoretical framework, however, the line of cases including Gore, Campbell, Williams, and Baker appears to be the product of conspicuous judicial protectionism of big corporate interests at the expense of plaintiffs, thus undermining the credibility of the rulings and indeed the Court as well. One wonders whether the highly publicized Texaco-Pennzoil case left an indelible impression on the Supreme Court regarding the impact of punitive damages on corporations and business in general. The Court played a minor role in this landmark litigation, ${ }^{256}$ but for the most part it watched from the sidelines as two giant oil companies used tort law and punitive damages to inflict severe damage on each other's economic value. In December 1987, the case settled ${ }^{257}$ but the litigation and its trial outcome shocked the business community. ${ }^{258}$ It showed that a single tort action with substantial punitive damages awarded by a jury can bankrupt public companies. Two years later in 1989, the Court embarked on its constitutional reformation with its decision in Browning-Ferris. ${ }^{259}$ In that case, Justice O'Connor argued in dissent that "[a]wards of punitive damages are skyrocketing."260 In 1991 in Haslip, she called punitive damages a "powerful weapon." ${ }^{261}$ And in 1993 in TXO, she called the punitive damages amount there "a monstrous award."262 In 1996 in Gore, she joined the majority that finally struck down high-multiple awards.

At first blush, Gore and Campbell seem like ideal candidates to impose order in the world of seemingly uncertain and unpredictable outcomes. The multiples in these cases were unusually high, and the cases seem like outliers. But the facts there differed significantly from Texaco-Pennzoil in important ways. Texaco-Pennzoil was a one-shot, "all-in" business litigation involving an entity-level transaction - the judicial outcome would substantially affect the litigants. On the other hand, Gore and Campbell concerned routine business transactions, and in both cases there was underlying evidence

256. It ruled that the federal district court should have abstained from issuing an injunction related to the posting of a bond for appeal in state court. Pennzoil Co. v. Texaco Inc., 481 U.S. 1 (1987).

257. Mnookin \& Wilson, supra note 33, at 308.

258. See Barbara Shook, Ex-Getty Directors Say No Pennzoil Deal Made, Hous. Chron., May 27, 1987, at D1 (quoting Getty Oil directors as saying that the case "sent shock waves through the international business community and [shook] investors' faith in America as a good and predictable place to do business"); Debra Whitefield, Texaco Shareholders Voice Views on Pennzoil Battle, L.A. Times, May 14, 1986 (noting that shareholders "expressed shock over the verdict").

259. Browning-Ferris Indus. of Vt., Inc. v. Kelco Disposal, Inc., 492 U.S. 257 (1989)

260. Id. at 282 (O'Connor, J., dissenting).

261. Pac. Mut. Life Ins. Co. v. Haslip, 499 U.S. 1, 42 (1991) (O’Connor, J., dissenting).

262. TXO Prod. Corp. v. Alliance Res. Corp., 509 U.S. 443, 473 (1993) (O’Connor, J., dissenting). 
of repeated, undetected tortious activities that would merit punitive damages to optimize cost internalization. ${ }^{263}$ Punitive damages would be consistent with the standard law and economics model of punitive damages as applied, for example, in Judge Posner's opinion in Mathias. ${ }^{264}$ The multipliers in Gore and Campbell appear to be outliers, but more importantly the two cases involved routine amounts of liability. The judgment amounts, \$2 million and $\$ 145$ million, were small sums to the defendants. A $\$ 2$ million judgment of punitive damages may be devastating to a small firm, but it would be a small amount in the operating budget and relative to the net worth of a large national corporation like BMW. And, while the $\$ 145$ million award in Campbell seems like an impressive award, at the time of the trial it was less than 1 percent of State Farm's policyholders' surplus. ${ }^{265}$ In relative terms, the award is equivalent to an $\$ 8,043$ judgment against a small entrepreneurial firm with a net worth of $\$ 1$ million. There is no question that the awards in Gore and Campbell in terms of absolute amounts were rather ordinary, and the freakish nature of the multipliers does not detract from the ordinariness of the action. These cases were wrongly decided. There was no need for Supreme Court intervention in these ordinary cases where the variance of outcome served a positive jurisprudential function.

The issue of whether an award is optimal cannot be answered by reference to the absolute sum or the multiple. ${ }^{266}$ Punitive damages can reduce social cost and enhance social welfare by optimizing cost internalization, or they can be inefficiently applied. Excessive punitive damages can lead to undesirable wealth transfers and impose large economic costs related to financial distress as seen in cases like Texaco-Pennzoil and BP Deepwater Horizon. Insolvency and financial distress impart social costs that reduce social wealth. In these cases, the wrongdoers fully pay for the harms inflicted on the plaintiffs through compensatory damages.

So what role should punitive damages play according to the Court? The answer is unclear after Williams and Baker. By holding that punitive damages cannot be used to punish a defendant for injuring nonparties, ${ }^{267}$

263. State Farm Mut. Auto. Ins. Co. v. Campbell, 538 U.S. 408, 415 (2003); BMW of N. Am., Inc. v. Gore, 517 U.S. 559, 573-74 (1996).

264. See supra Section II.A.

265. In 1989, the year of the trial, State Farm's policyholders' surplus, which is the equity in a mutual insurance company, was $\$ 18,028,886,000$. A.M. Best Co., Best's Insurance Reports: Property-Casualty 2720 (1990). Currently, State Farm is ranked 37th in the Fortune 500 among U.S. companies with equity of over $\$ 63$ billion, Fortune 500, Fortune, May 23, 2011, available at http://money.cnn.com/magazines/fortune/fortune500/2011/ index.html, and 116th in the Fortune 500 among all global companies, Global 500, ForTune, July 25, 2011, available at http://money.cnn.com/magazines/fortune/global500/2011/.

266. See TXO, 509 U.S. at 467 (Kennedy, J., concurring in the judgment) ("The Constitution identifies no particular multiple of compensatory damages as an acceptable limit for punitive awards; it does not concern itself with dollar amounts, ratios, or the quirks of juries in specific jurisdictions.").

267. Philip Morris USA v. Williams, 549 U.S. 346, 356-57 (2007); see also Campbell, 538 U.S. at $422-23$ 
Williams shields recidivist tortfeasors from paying the full cost of their harmful activities. ${ }^{268}$ Is there any doubt that cigarette manufacturers would escape liability for causing harm to thousands of consumers if they were dead, could not prove causation, or declined to sue for whatever reason?269

Williams cannot be explained, let alone justified, on the theory of cost internalization, which leaves two competing explanations: a pro-business protectionist policy or a theory of punitive damages as retribution. However, I glean another explanation by asking a simple question: why did the Court decide Williams differently from Gore and Campbell? Notably the Court declined to reject the $\$ 79.5$ million punitive award, a multiple of $96.8 \mathrm{x}$, through the simplest route. It could have applied Campbell's single-digit cap to strike down the award, which was an argument that Philip Morris advanced. ${ }^{270}$

Williams posed several new problems for the Court. As noted previously, it was the only case involving personal injuries with clear reprehensibility. Other major cases concerned economic torts. The Court declined to apply Campbell perhaps because it wanted to preserve greater flexibility for deviations from Campbell in personal injury cases. Superficially, Williams also seems similar to Gore and Campbell in that a $\$ 79.5$ million award would not have caused Philip Morris financial distress. But the facts in Williams suggest an exposure to repeated high severity awards due to (1) the high number of physically injured victims, (2) the substantial probability of punitive damages in each case, and (3) the substantial probability of high multiples. These facts distinguish Williams from Gore and Campbell. High frequency, high severity punitive awards collectively could cause financial distress not only for Philip Morris but quite possibly for the entire cigarette manufacturing industry-something that cannot be said for the auto industry in Gore or the insurance industry in Campbell. Clearly, no defendant should be protected from paying fully compensatory damages. However, economic policy should be a factor in discretionary awards when they could cause financial distress to a firm or an entire industry. In this sense, Williams represents a series of repeated cases that in the aggregate could constitute the equivalent of a one-shot, high-variance outcome like that seen in Texaco-Pennzoil.

Thus, Williams is unique on its facts. The Court's holding walked a fine line between permitting high levels of liability, including punitive liability that may recapture some cost of escaped liability, and mitigating the financial distress resulting from punitive cost imposition. The Court may have been concerned not only with the solvency of Philip Morris, but also with the financial effects of unchecked punitive damages on the entire cigarette

268. Law and economics scholars disagree with the approach taken in Williams. See Calandrillo, supra note 17, at 815-17. Other commentators have suggested that Williams could spell the end of the law and economics theory of deterrence in punitive damages. See Colby, supra note 17 , at $467-79$.

269. See supra notes $136-137$.

270. Williams, 549 U.S. at 351-52. 
manufacturing industry. The ruling preserved judicial flexibility for upward deviance from Campbell in personal injury cases in future cases, permitted punitive damages in cigarette cases, and partially shielded the cigarette industry from the economic costs of financial distress caused by punitive liability vis-à-vis compensatory damages. All in all, Williams can be interpreted as a practical, rough-cut compromise in the economic regulation of tort liability as the Court surveyed the landscape of future cigarette litigation.

A year later, the Court decided Baker. To date, Baker is arguably the most important punitive damages case for three reasons. First, the intellectual candor and clarity in stating the core problem permit a proper framing of the theoretical issue. It correctly identified the problem of "stark unpredictability"271 and the elimination of "outlier cases" as the solution to the core problem of variance. ${ }^{272}$ Second, in capping the multiple at $1 \mathrm{x}$ in maritime cases, the Court may have laid the foundation for all federal actions where punitive damages are recoverable but not otherwise defined by statute. The holding in Baker is limited to maritime cases, but its rationale is portable to other federal actions. Third, Baker foretells further constitutional restrictions on state punitive damages awards. Quoting Campbell, the Court reiterated that when compensatory damages are substantial, a ratio lower than just the single-digit cap may be the outermost limit of due process. ${ }^{273}$ In footnote twenty-eight, the Court suggested that when class actions achieve compensation for a large number of potential plaintiffs, the constitutional limit may be a multiplier of $1 x .^{274}$ This prompted Justice Ginsburg to ask, "On next opportunity, will the Court rule, definitively, that 1:1 is the ceiling due process requires in all of the States, and for all federal claims?"275

The Court in Baker suggested that "ranges of variation might be acceptable or even desirable if they resulted from judges' and juries' refining their judgments to reach a generally accepted optimal level of penalty and deterrence." ${ }^{276}$ Despite suggestions that Williams spells the end of deterrence as a rationale for punitive damages, Baker reminds us that the Court is concerned with optimal deterrence-based liability. The Court also suggested that variance would be desirable if it tends to produce an optimal level of deterrence. The problem is that the Court perceived variance as being inherently a bad thing and saw no positive role for variance to play in litigation. This attitude explains the instrumental policy of "pegging punitive to compensatory damages using a ratio or maximum multiple." ${ }^{277}$ In doing so, the Court recognized that its policy could be criticized as "smack[ing] too much

271. Exxon Shipping Co. v. Baker, 554 U.S. 471, 499 (2008).

272. Id. at 504, 506, 513 .

273. Id. at 514-15 (quoting State Farm Mut. Auto. Ins. Co. v. Campbell, 538 U.S. 408, $425(2003))$.

274. Id. at $515 \mathrm{n} .28$.

275. Id. at 524 (Ginsburg, J., dissenting).

276. Id. at 500 (majority opinion) (emphasis added).

277. Id. at 506 . 
of policy and too little of principle." 278 Thus, a theory of punitive damages is needed, and the theory must account for the role of variance in punitive damages.

\section{CONCLUSION}

The real issue in the debate over punitive damages is the variance and unpredictability of awards. Only a small class of awards poses significant economic problems warranting additional legal constraints beyond the traditional state law standards. This small class of cases is characterized by low frequency of occurrence and high severity of damages, with the latter measured by losses sufficient to cause financial distress. Litigating parties bear risk and engage in risk management. Under various conditions, each party has an opportunity to take advantage of risk arbitrage opportunities arising from the fact that the counterparty is exposed to greater risk and thus will concede discounts to settlement values. In cases of ordinary expected liability, the plaintiff bears more risk because she is risk averse, she confronts an all-or-nothing proposition at trial, and she has greater opportunity costs. In cases involving potentially catastrophic risk, a corporate defendant bears greater risk because of increased bankruptcy risk and cost of capital, resulting in real losses of substantial economic value through corporate financial effects. Punitive damages substantially affect these risk calculations.

The normative theory advanced here flows from the observation that punitive damages mitigate risk arbitrage by both parties. When punitive damages are within the range of normal expectations, even if they result in a high multiple and dollar value, they serve the legitimate function of offsetting a corporate defendant's potential for risk arbitrage in settlement. However, when punitive damages belong to the class of low frequency, high severity risks (which is a far smaller subset of a small class of cases in which punitive damages are awarded), the risk arbitrage opportunity belongs to the plaintiff. The policy goal is to mitigate these mutual arbitrage opportunities.

The Supreme Court reformation of punitive damages is overbroad. Gore, Campbell, and their progeny were wrongly decided and wrongly reasoned from a deterrence theory of punitive damages. With the possible exception of Williams, they were unnecessary interventions in favor of corporate interests. Accordingly, they smack of pro-business protectionism without nuance or theoretical foundation, thus undermining the rulings and the Court's credibility.

There are legitimate reasons to protect corporate defendants within certain limits. Punitive damages should be restricted only in a limited number of cases in which the punitive damage award is a high severity event involving a substantial risk of financial distress. Otherwise, the economic costs of such liability may overdeter and inflict greater social cost than any adverse incentives placed on defendants by inadequate liability assessment. In all 
[Vol. 111:ppp

other cases, however, there is no principled reason to protect corporate defendants from large punitive damages awards. 